
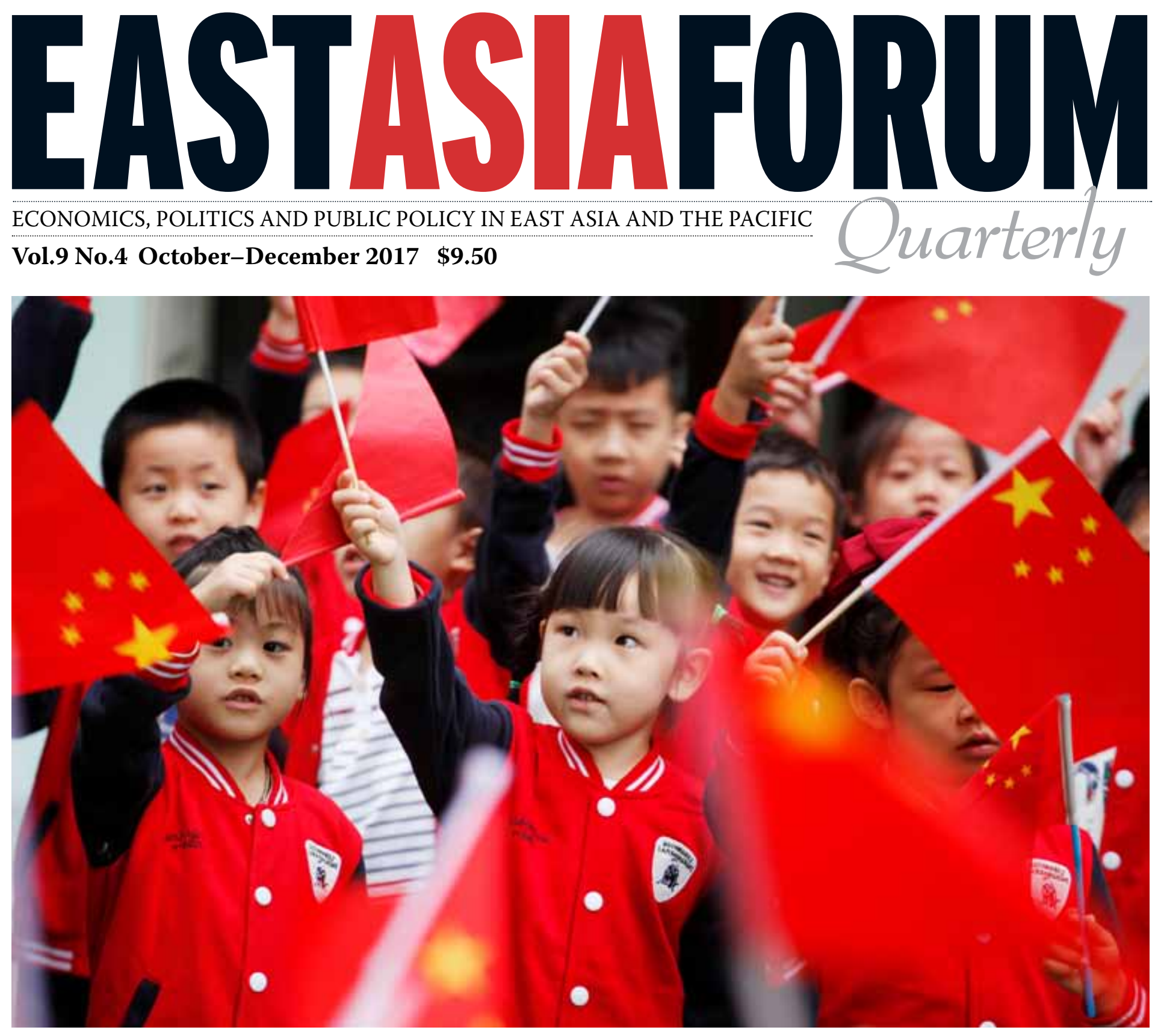

\title{
China's influence
}

David M. Lampton Negotiation key to balancing Sino-US interests Allan Gyngell Australia's China policy challenge

Andrew J. Nathan Self-interest shapes policies for the international order

Wanning Sun Chinese-language media and social cohesion in Australia

Ien Ang Engaging Australia's Chinese diaspora ... and more

ASIAN REVIEW - Kent E. Calder: The rebirth of Eurasian geopolitics 


\section{EASTASIAFORUM}

Quarterly

ISSN 1837-5081 (print) ISSN 1837-509X (online)

\section{From the Editors' desk}

One of the biggest questions in global affairs is how a rising China will shape the world beyond its borders. What kind of influence will China seek, how will it seek it, and to what ends? These questions were central to the deliberations of the recent 19th Party Congress.

China's influence is a hot-button issue in Australia following a string of media allegations about links between the Chinese Communist Party (CCP) and members of the Chinese diaspora who have mobilised to defend or advance Beijing's agenda abroad. The media coverage raises alarms about Beijing's intentions at a time when China's power is growing. State President and CCP Secretary-General $\mathrm{Xi}$ Jinping's signature policy platform is the 'China Dream' (中国梦), centred on 'the great rejuvenation of the Chinese nation' (中华民族大复兴). Yet the commitments to multilateral institutions and a 'shared community' in Xi's Party Congress report seek to reassure the world about what China's ambitions mean for it.

In this $E A F Q$ we examine China's influence from several perspectives. On a global scale, we address China's engagement with the liberal international order and multilateral institutions (Andrew Nathan, Zhong Feiteng). We consider China's efforts to establish itself as the dominant power in East Asia (Richard McGregor), the importance of the Belt and Road Initiative in expanding Chinese influence (David Lampton, Evelyn Goh and James Reilly), state-owned enterprises (Brodsgaard), regional anxieties about China's influence (Chitrapu Uday Bhaskar) and Southeast Asian responses to Chinese power (Renato Cruz De Castro). Chinese influence in Australia is a frontline issue, including in politics (Alan Gyngell, Peter Drysdale and John Denton), on university campuses (Brian Schmidt), in the media (Wanning Sun) and in the Chinese-Australian community (Ien Ang). Taken together, the discussion of Chinese influence in Australia urges greater sophistication in conceptualising the problem and greater maturity in formulating responses. These issues will resonate wherever governments and communities are confronting the opportunities and challenges of China's rise and its exercise of power.

Asian Review examines grand strategy in Asia (Calder), Southeast Asian political trends (Slater), Duterte and China (Cruz de Castro) and Asia's global trade strategy (Basri).

\section{Ben Hillman and Tom Westland}

CONTENTS

\section{DAVID M. LAMPTON}

Negotiation holds the key to balancing SinoUS interests

\section{ALLAN GYNGELL}

Engagement, discipline, trust: Australia's policy challenge

\section{ANDREW J. NATHAN}

Self-interest shapes policies for the international order

\section{PETER DRYSDALE AND JOHN DENTON}

Australia must move beyond 'Cold War thinking'

\section{RICHARD MCGREGOR}

Does Japan need the Pax Americana?

15 KJELD ERIK BRODSGAARD

Party control of state-owned enterprises

17 DAN SLATER

ASIAN REVIEW: Dark days for democracy in Southeast Asia

21 KENT E. CALDER

ASIAN REVIEW: The rebirth of Eurasian geopolitics

23 RENATO CRUZ DE CASTRO

ASIAN REVIEW: From foes to best friends: Duterte's policy switch

25 M. CHATIB BASRI

ASIAN REVIEW: Pursuing growth: ASEAN against global trade trends

\section{BRIAN P. SCHMIDT}

Campus connections matter

29 ZHONG FEITENG

China's grand strategy in a new era

\section{WANNING SUN}

Chinese-language media and social cohesion in Australia

33 EVELYN GOH AND JAMES REILLY China's Belt and Road Initiative

\section{CHITRAPU UDAY BHASKAR}

How will India contend with China's growing power?

\section{IEN ANG}

Engaging Australia's Chinese diaspora

COVER: Children at a Chinese National Day celebration at a kindergarten in Hangzhou. Picture: Reuters. 


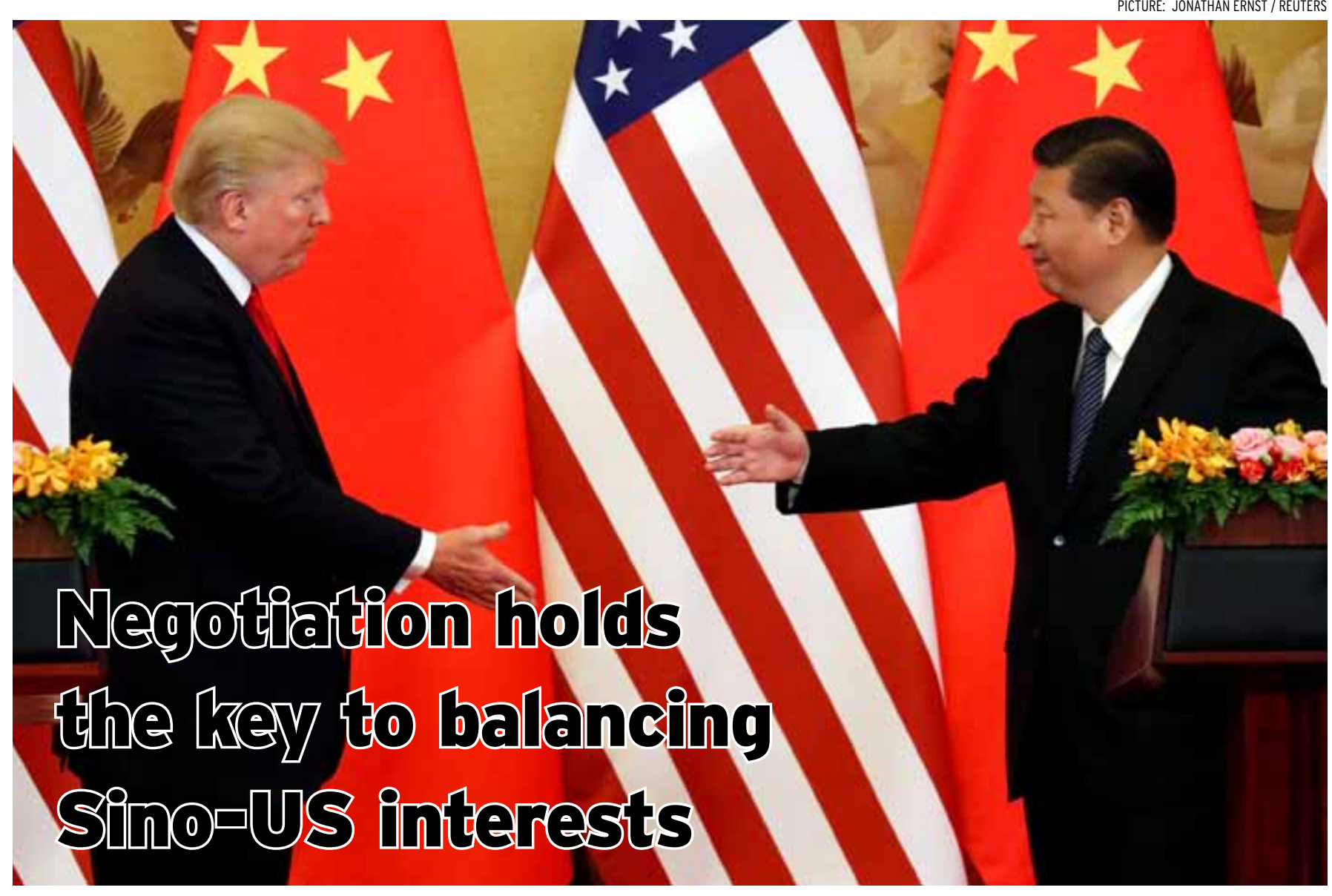

\section{DAVID M. LAMPTON}

\section{$\mathbf{F}$} ROM 1945 to 2016 the United

States used its economic, military and ideological power to build institutions, alliances and regimes that contribute to global growth and avoiding great-power war. In doing so, it fostered a new constellation of powers, including China, to which it now must adapt. Washington increasingly must win cooperation rather than compel it.

On coming into office, US President Donald Trump put several contentious issues with China on the back-burner in the hope of achieving his primary goal-North Korea's denuclearisation. When that failed, the front-burner of the US-China relationship became crowded with previously repressed issues, several of which could become significant problems if not more carefully managed than the Trump administration has thus far demonstrated the capacity to achieve-US freedom of navigation operations in the South China Sea, talk of steel and aluminium tariffs, weapons sales to Taiwan, threats to tighten technology and investment flows, and secondary sanctions on Chinese entities.

In Beijing, the driving consideration in recent political life has been the convening of the 19th Party Congress. In the run-up to this conclave, Party General Secretary Xi Jinping wanted to seem cooperative in Washington while appearing tough on the United States at home. In short, $\mathrm{Xi}$ has been in power-consolidation mode. Being soft on America is inconsistent with building his nationalistic coalition domestically.

Xi's growing domestic strength can be seen in his increased clout in the military; the promotion of the Communist Party, rather than the more technocratic State Council, as China's leading organisation; and in more repression and social control.

In terms of foreign policy, Beijing has become progressively more assertive under $\mathrm{Xi}$ in safeguarding national interests and winning more say for China abroad. Beijing views Washington as increasingly alienated from its traditional friends abroad and gridlocked at home. As the People's Daily put it, it is 'a bizarre soap opera'.

Beijing is making international infrastructure investments through its Belt and Road Initiative on a large scale. This nominally US $\$ 1$ trillion effort aims to make China 


\section{EASTASIAFORUM} EDITORIAL STAFF

\section{Issue Editors}

Benjamin Hillman is Associate Professor in political science at the Crawford School of Public Policy, ANU, and a specialist on China, comparative government and democracy.

Tom Westland is the Wong-Calthorpe Cambridge-Australia scholar in economic history at the University of Cambridge.

\section{Series Editors}

Peter Drysdale, Head, East Asia Forum and East Asian Bureau of Economic Research, Crawford School of Public Policy, ANU.

Shiro Armstrong, Co-director, Australia-Japan Research Centre, and Editor of East Asia Forum, Crawford School of Public Policy, ANU.

\section{Editorial Staff}

Coordination: Brandon Smith, Sam Hardwick. Editing: Rosa Bishop, Alison Darby, Oliver Friedmann, Hannah Harmelin, Sam Hardwick, Nick Horton, Nishanth Pathy, Michael Wijnen, Catherine Yen, Ebony Young, ANU.

Editorial Advisers: Peter Fuller, Max Suich.

Production: Peter Fuller, Words \& Pics.

Email Peter.Drysdale@anu.edu.au, Shiro.Armstrong@anu.edu.au.

The views expressed are those of the individual authors and do not represent the views of the Crawford School, ANU, EABER, EAF, or the institutions to which the authors are attached.

\section{ANU PRESS}

Published by ANU Press The Australian National University Canberra ACT 2601, Australia

Email: anupress@anu.edu.au Web: http://press.anu.edu.au the connectivity hub of its region and beyond. There are, of course, enormous challenges facing Beijing in this effort. Still, the initiative holds the prospect of increasing Beijing's influence. The United States dismisses it too easily.

Some of this is good news for a world order deeply influenced by US policies since World War II. Increasing China's role in the trade system and encouraging Beijing to provide international public goods have been features of US policy for decades. But China also uses its growing strength to press sensitive issues. It is possible Beijing will overplay its hand.

So what might the United States usefully do? Washington should focus on three issues. First, how to foster an economic balance of power in Asia that would help promote regional stability? Second, how to achieve more reciprocity in Sino-US relations? And third, how to address the North Korean nuclear and missile problem?

The shortening economic leg of US power in Asia weakens the United States' capacity to maintain a balance of influence in the region. It also means the United States is not deriving maximum benefit from the region's dynamic growth. And by questioning so many bilateral and multilateral trade agreements, the Trump administration is squandering US influence and prosperity.

A central part of Xi Jinping's geoeconomic vision is to expand regional links and promote urbanisation and growth on China's periphery, making China the central node in this growing region. For Beijing, this means north-south connectivity-creating goods and services supply chains originating in China and extending to the Indian Ocean, the South China Sea, Andaman Sea, Bay of Bengal and beyond.
The United States should become more involved in the construction of regional infrastructure, and collaborate to foster linkages that are not just north-south, but eastwest. East-west means from India to Vietnam, through Myanmar, Thailand and Cambodia, and on to Japan and the wider Pacific. Unless it wants Asia to become a sphere of one power's influence, the United States must diversify. Washington cannot do this alone and needs the private sector to broaden its horizons as well.

$\mathbf{T}$ URNING to reciprocity, when China joined the World Trade Organization in 2001, its trade and financial involvements abroad grew enormously, as did its global trade surplus and bilateral trade surplus with the United States. Consequently, Beijing soon had the technology, capital and capacity to seize the opportunities of openness abroad without providing reciprocal access to China for the United States and others. Industrial policy, eventually under the signboard of 'Made in China 2025', became progressively prominent.

Further, from about 2008 on, the pace of domestic economic, financial and foreign trade liberalisation slowed. China's world trade partners came to realise that as China leapt outward to seize opportunities, it did not reciprocally open itself in areas where foreigners enjoyed comparative advantages, particularly in services. Consequently, the issues of 'reciprocity' and 'fairness' have moved front and centre in Sino-American relations.

Now, US companies are asking themselves why Chinese entrepreneurs should be able to freely acquire US service and technology firms when these areas in China are closed to foreigners. 
Yet it is one thing to identify inequities and another to find remedies that don't hurt US interests and innocent bystanders more than Beijing. Limiting Chinese investment into US employment-generating firms diminishes domestic US job opportunities.

While US feelings of resentment mount, finding ways to enhance reciprocity that don't injure Americans and innocent bystanders is hard. On the other hand, ignoring the problem invites extremist proposals at home and contempt in Beijing.

Finally, the issue of North Korea. When leaving office, former president Barack Obama told Trump that his most pressing national security challenge would be North Korea's relentless efforts to further develop its nuclear weapons.

$\mathbf{T}$ RUMP thought his predecessors had been right in pressing Beijing to put more pressure on North Korea, and that they were correct in their assessment that Beijing had sufficient means to do so. But Trump also thought his predecessors had gone wrong by not making it worth Beijing's while to apply the necessary pressure.

So the new US President suggested that Washington would give Beijing concessions in other areas-trade and Taiwan among them-in exchange for pressure on North Korea. But was this credible? Would Washington really ease off on Chinese unfair trade practices? Could the White House ignore the Taiwan Relations Act in return for Beijing's cooperation on North Korea? Of all the reasons that Trump's approach has not worked out, however, the dominant one is that Pyongyang is able to resist advicefrom China or elsewhere-that it fears would be lethal.

Consequently, the US administration is left with the same stark choices as its predecessors, except that Trump has staked even more on the issue and North Korea is further down its path to deliverable nuclear weapons. The United States' options-none of them easy-fall into three categories.

First, it could accept North Korea as a nuclear weapons state and deter Pyongyang from using them, as it did with the Soviet Union and China.

Second, it could persist in a policy of tightening sanctions, knowing there are limits to the pressure China will apply. All the while, Pyongyang builds more warheads and the means of their delivery. And Beijing, I believe, actually prefers a North Korea with nuclear weapons that remains peaceful to a nuclear-free Korean peninsula achieved through military conflict.

Finally, the United States could use force to try to destroy North Korea's nuclear-related capacities, or the regime entirely, knowing that Pyongyang's death throes could take hundreds of thousands-or many more-of South Koreans and others with it.

It is time for Washington, in close

The United States is no

longer positioned to

compel cooperation - it

must be negotiated, and

Washington must seek

a balance of power and

interests consultation with its South Korean and Japanese allies, to consider acknowledging that North Korea has a modest nuclear deterrent, and to deter North Korea's use of these capabilities and proliferation activity.

( HINA does not want to formally accept North Korea as a nuclear state. This position is understandable, but what can Beijing do to advance this desire? In the end, Beijing's consistent policy of preferring the absence of war to a nuclear-free peninsula suggests it already has accepted what it says it will not.

The US-China relationship is fraught with problems and it will be for the foreseeable future. What Beijing and Washington must do is manage the challenges. The United States is no longer positioned to compel cooperation-it must be negotiated, and Washington must seek a balance of power and interests.

As we contemplate the prospect of endless Sino-American abrasion and negotiation, remember that the three decades from the founding of the People's Republic of China in 1949 to 1979 saw two wars involving China and the United States and virtually no bilateral trade. The next almost 40 years have seen no Sino-American wars and huge welfare improvements in both countries through cooperation. Let's remember past achievements as we deal with current and future frustrations. EAFO

David M. Lampton is George and Sadie Hyman Professor and Director of China Studies at Johns Hopkins Paul H. Nitze School of Advanced International Studies and Chairman of The Asia Foundation. His most recent book is Following the Leader: Ruling China, from Deng Xiaoping to $\mathrm{Xi}$ Jinping. 


\section{MUTUAL RESPECT}

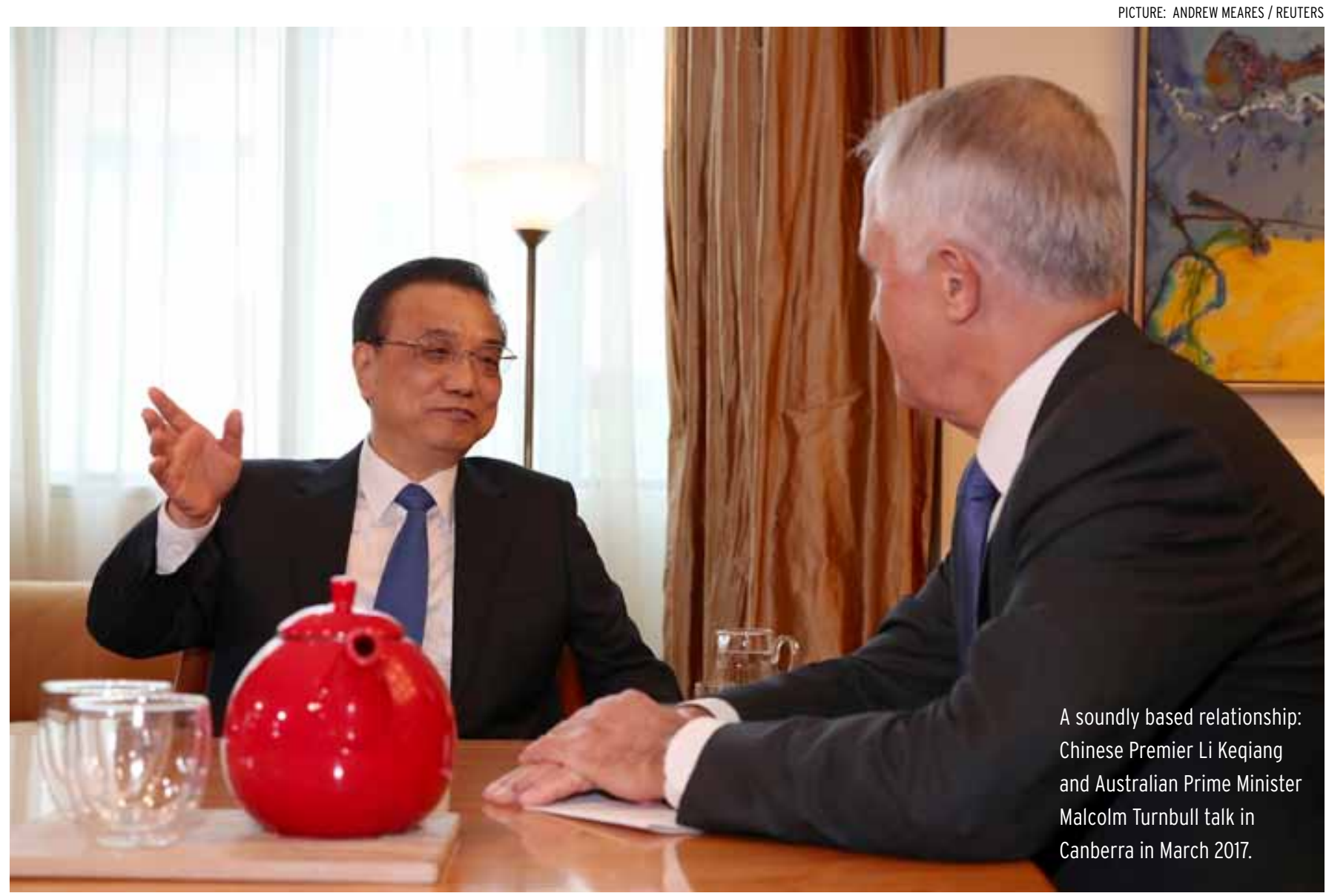

\section{Engagement, discipline, trust: Australia's policy challenge}

\section{ALLAN GYNGELL}

N ITS combination of complexity and consequence, Australia's engagement with China is the most important issue in Australian foreign relations.

Comfortable assumptions from the 1990s and early 2000s that China's economic growth and its integration into the international system would gradually make it more like a liberal democracy have so far proved illusory. In reinforcing Communist Party control, President Xi Jinping has forcefully reminded us of the clear systemic differences in the way the Chinese party-state operates, the demands it makes of its citizens and the values it seeks to impose.

$\mathrm{Xi}$ is certainly the most ambitious Chinese leader in decades. He has moved decisively away from Deng Xiaoping's injunction to China to hide its capabilities and bide its time, and is instead seeking a larger international role and greater influence.

China now sees itself as a great power. This shift was inevitable. It is hard to 'hide and bide' when you are, measured in purchasing power parity terms, already the largest economy in the world.

Australia's bilateral trade with China in goods and services topped AU\$155 billion (US\$122 billion) in 2016, growing three times faster than world trade as a whole. China was Australia's largest export market and largest source of imports. It was also the largest source of foreign investment for the third consecutive year, with AU\$47.5 billion (US\$37.3 billion) in proposals.

Around 1.2 million Chinese tourists 
arrived in Australia last year, second only in number to New Zealanders, a number likely to be exceeded next year. Almost 170,000 Chinese students are studying in Australia. Australia's services exports to China now exceed the value of its iron ore exports to Japan and South Korea combined.

There is a side-bar story attracting some attention, about whether the United States is a bigger economic partner for Australia than China. The objective seems to be to suggest that Australia does not need to worry so much about China, or that there are alternatives to it. It's a curious argument, mixing historical stocks of investment into investment flows and throwing in calculations like ease of doing business or the size of Australian-owned businesses in the other country.

But for any practical purpose of managing Australia's economic prospects the debate is pointless. Whichever way you look at it, if things go badly wrong, either because a financial crisis or trade war causes China's growth to slow suddenly, or Beijing cuts back on trade or investment in Australia-perhaps to register disapproval of its policy positions-the consequences would be painful. Australia has no immediate alternative markets for its products or sources of investment to fill the gap.

Australia would adjust over time, but many of the other things it wants to do, including funding an ambitious defence procurement program, would become much more difficult. Important aspects of Australian domestic policy such as budget sustainability, the foreign investment regime, and the viability of the tertiary education system also have a vital China dimension to them.

And China is systemically important to the health of the entire international economy, as the largest contributor to global growth since the 2008 global financial crisis.

In a security sense, too, the scale and nature of China's activities are transforming the international order. It is hard to think of a major issueNorth Korea's nuclear program, maritime security in East Asia, development challenges in the South Pacific, climate change-that does not involve China in some way. China is also an important player in every major international institution whose outcomes Australia wants to influence, from the United Nations and G20, to APEC and the ASEAN Regional Forum.

We cannot know what China's strategic ambitions will ultimately be or how successfully it will manage its domestic problems. Australia can and should form views about these questions and try to help nudge developments towards the outcomes it prefers, but it cannot conduct its relationship on the basis of confident assumptions about China's international behaviour or domestic outlook.

So how should Australia approach and conduct its bilateral relations with China?

Diplomacy is a skill-set,

not a profession, and it is

exercised by policymakers

as much as officials.

It involves intense

interaction ...
First, it must accept that the response to any threats to the integrity of Australia's political system, or to the inclusiveness of our society, from China or elsewhere, lies overwhelmingly in its own hands; in the strength of its institutions and its determination to defend them.

Australia has never had to manage a relationship of this complexity before. But it has a surprisingly solid place to begin in the formal declaratory positions of the Australian governments led by Kevin Rudd, Julia Gillard, Tony Abbott and Malcolm Turnbull. These have been remarkably consistent.

The core of the policy response has been to acknowledge that China's rise is both legitimate and welcome, but to note that the world into which China rises needs to be one in which agreed rules are kept, all voices are heard and China acts responsibly. Of course, many tough, complex, policy choices follow, but that is a clear starting point.

More contestable has been the assertion that Australia does not have to choose between its strategic alignment with the United States and its economic ties with China.

All of Australia's political leaders have offered versions of that bromide. Prime Minister Turnbull most recently said that a choice between Beijing and Washington was an 'utterly false choice.' But that is true only in the sense that Australia is unlikely ever to be confronted with an ultimatum asking it to choose between preserving its trade with China and formally abrogating the ANZUS treaty.

In reality, Australia is choosing every day-to sign on to the Belt and Road Initiative, to conduct freedom of navigation patrols in the South China Sea, to urge one course or another on its Southeast Asian neighbours. These choices will sharpen as the stresses in 
the relationship between Washington and Beijing increase.

It feels at present as though China is becoming a proxy for the United States in the Australian national security debate. Because of the difficulty of talking frankly about the United States in circumstances where the Trump administration's policies veer wildly and its values are uncertain, a posture of resolute opposition to China is becoming seen as a measure of loyalty to the alliance.

That's the wrong way to deal with either China or the United States.

To make effective choices in all these areas, Australia is going to need much better insight into the thoughts of Chinese policymakers and the processes of Chinese policymaking. Australia will need to understand China as well as it does the United States, not because it will always agree with China, but because it will have more chance of shaping China's behaviour if it is engaged and knowledgeable.

As China moves to develop and shape multilateral institutions, Australia needs to be there to help reinforce open and inclusive trade and economic norms, to support high environmental standards and to make the case for all voices to be heard. It will not achieve this by shouting from the sidelines.

The investment of time and education this will require from Australia's political leaders, officials and business people is enormous. Australia is seriously underprepared for this. Differences in values and government structures inevitably make the task more difficult and affect the intimacy of Australia's engagement.

But that's where foreign policy comes in. The role of foreign policy is precisely to manage differences. The world Australia is moving into,

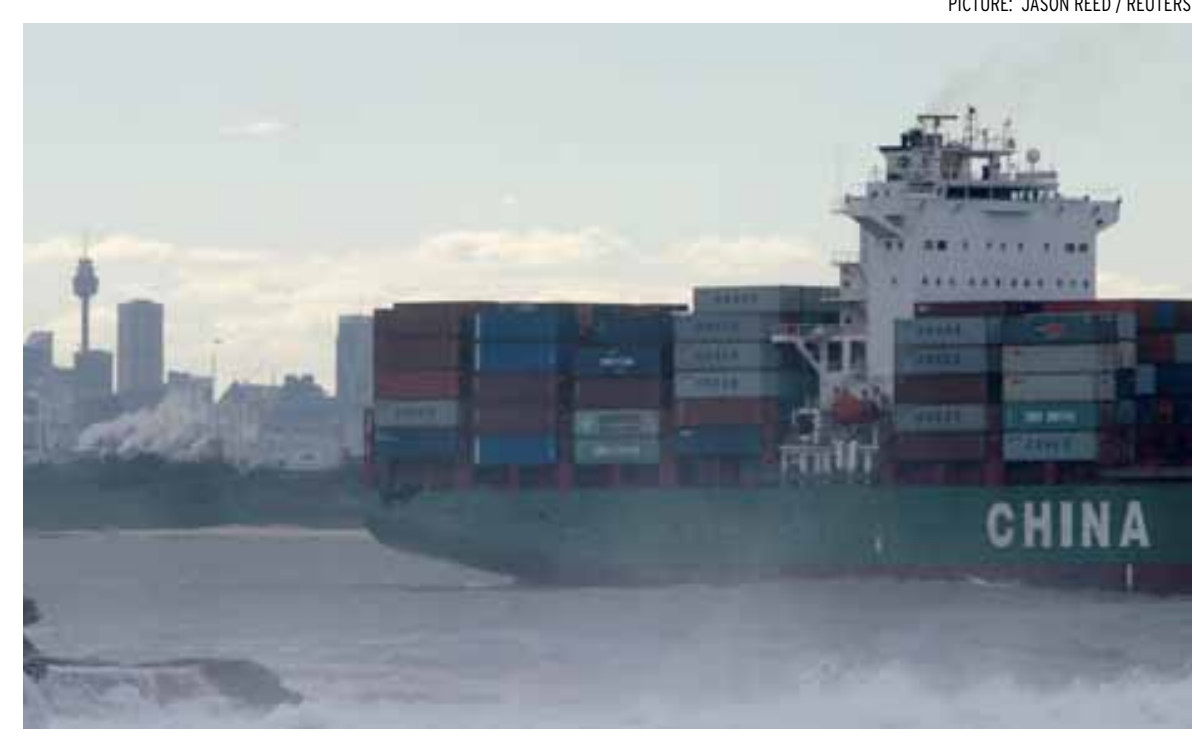

A China Shipping Line container vessel sets sail from the Botany Bay container port, Sydney. Australia's bilateral goods and services trade with China exceeded AU\$155 billion in 2016.

more nationalist, more protectionist, more nativist-post-truth and postTrump-is one in which the functions and traditions of foreign policy, marginalised in recent decades, will be increasingly relevant.

Within the broader scope of statecraft, the work of foreign policy is to expand the space in the international system within which Australia can operate and to make sure that at critical points it has choicesthat it is not forced or coerced into certain responses. That involves diversifying Australia's markets and partners.

Foreign policy emphasises sovereignty, reciprocity and negotiation. It considers issues through a comprehensive prism, balancing, weighing and incorporating the different parts of the relationshipthe purely bilateral elements and the common international objectives, the economic and the strategic, the values and the interests.

It then pursues these national objectives through creative diplomacy. Diplomacy is a skill-set, not a profession, and it is exercised by policymakers as much as officials. It involves intense interaction and works towards the slow building of trust.

Those elements are precisely what Australia needs if it is successfully to conduct its bilateral relationship with China. Australia needs deep engagement, discipline, patient trust-building, balanced reciprocitybearing in mind their different systems and interests - and an insistence on non-interference in its domestic political processes.

With China, we know that what works best is consistency of message, delivered clearly but in an atmosphere of mutual respect. China is by no means alone in this.

To state this objective is not hard. But its effective execution will be one of the most difficult and consequential things Australia has had to do as a country. EAFQ

\section{Allan Gyngell is Honorary Professor at The Australian National University, National President of the Australian Institute of International Affairs and former Director-General of the Office of National Assessments.}




\section{A CONSERVATIVE POWER}

\section{Self-interest shapes policies for the international order}

\section{ANDREW J. NATHAN}

HE dramatic increase in Chinese economic, military and soft power since the 1990s has generated rising concern that Beijing seeks to overturn the liberal international order. This order, created during a period of US dominance after World War II and sustained until now by US power, consists of a set of norms and institutions that promote free trade and other 'open' economic interactions, and establish rules-based procedures for settling interstate disputes peacefully.

Some believe that China seeks to change this order in fundamental ways. Amitav Acharya, for example, writes that 'It is a fallacy to assume that just because China, India, and other rising powers have benefitted from the liberal hegemonic order, they will abide by its norms and institutions. They may not seek to overthrow it but push for changes that might significantly alter the rules and institutions of that order.'

But China's relationship to the liberal international order is essentially the same as that of other major states because in most respects this order serves Chinese interests. China has joined the agreements and institutions that make up the liberal international order and it complies with these regimes' requirements about as much as other major states do.

Each state works to shape and reshape international regimes to better serve its own interests and China is no exception. It seeks to influence, but not to overthrow or fundamentally alter, the liberal international order.

A variety of theories have been proposed for what drives China's foreign policy, including in international regimes. One set of theories sees China promoting a particular ideology or vision of the international system and its role within it, such as the principle of sovereignty, a multi-polar world, Asian values, or Chinese domination.

Alternatively, China's policies can be seen as pragmatic responses to specific national interests, such as protecting its material welfare, enhancing its influence and diminishing the influence of rival powers like the United States. An investigation of China's behaviour in international regimes can help to clarify what type

\section{China often defends}

\section{the more old-fashioned}

\section{interpretation of}

sovereignty against

efforts to reinterpret it in

a more limited way. China

in this sense is more of a

status quo power than the

United States of goals it is seeking and throw light on the larger question of whether China's rise supports or threatens the liberal international order. A review of selected international regimes supports the view that China's negotiating positions are interestbased.

In regional trade negotiations, China's position favours the further opening of world markets to manufactured exports. When the Trans-Pacific Partnership (TPP) was being negotiated, China showed an interest in it, but not a desire to join, presumably because the TPP framework imposed environmental and labour rights conditions that Chinese policymakers viewed as unfavourable to China's interests. It has instead worked to join or create with others bilateral and regional free trade agreements, such as the ChinaASEAN Free Trade Area and the Regional Comprehensive Economic Partnership, which set lower standards than the TPP on environmental and social protections.

China's participation in the existing arms control and disarmament (ACD) regime also supports the strategic status quo. China backs opposition to North Korean and Iranian nuclear weapons development and proliferation and it supports the further development of the ACD regime.

Yet many of its specific negotiating positions for the ACD regime's development aim to serve its own strategic interests by weakening or constraining areas of US superiority. 
China supports the declaration of nuclear-free zones, which the United States, as the dominant nuclear power, does not. China also backs proposed treaties to ban the first use of nuclear weapons, to ban the development of anti-ballistic missiles and to ban an arms race in outer space-all areas in which the United States enjoys advantages.

In short, China is a supporter of the ACD regime as such, but like other countries it pursues its own interests with respect to how that regime is applied and developed.

Over the past quarter-century China has exerted considerable influence over the way the international human rights regime works. In the UN Human Rights Council (UNHRC), China and cooperating states pushed a principle of universality, which reduces the degree to which individual countries are singled out for targeted attention. The current process of universal periodic review, which China helped promote, subjects every state to review by the council, but does so in a way that allows the state being reviewed and its sympathisers to heavily shape the agenda of the review.

Similarly, China was one of the promoters of a UNHRC initiative to have each state submit a Human Rights Action Plan, which allows each state to put forward its own interpretation of how international human rights norms should be interpreted for application in that country. China has also worked to restrict the role of non-governmental organisations in the council and in the treaty bodies, and to restrict the length and content of mandates given by the council to the so-called special procedures. The net effect of these efforts has been to position China in compliance with self-set priorities and

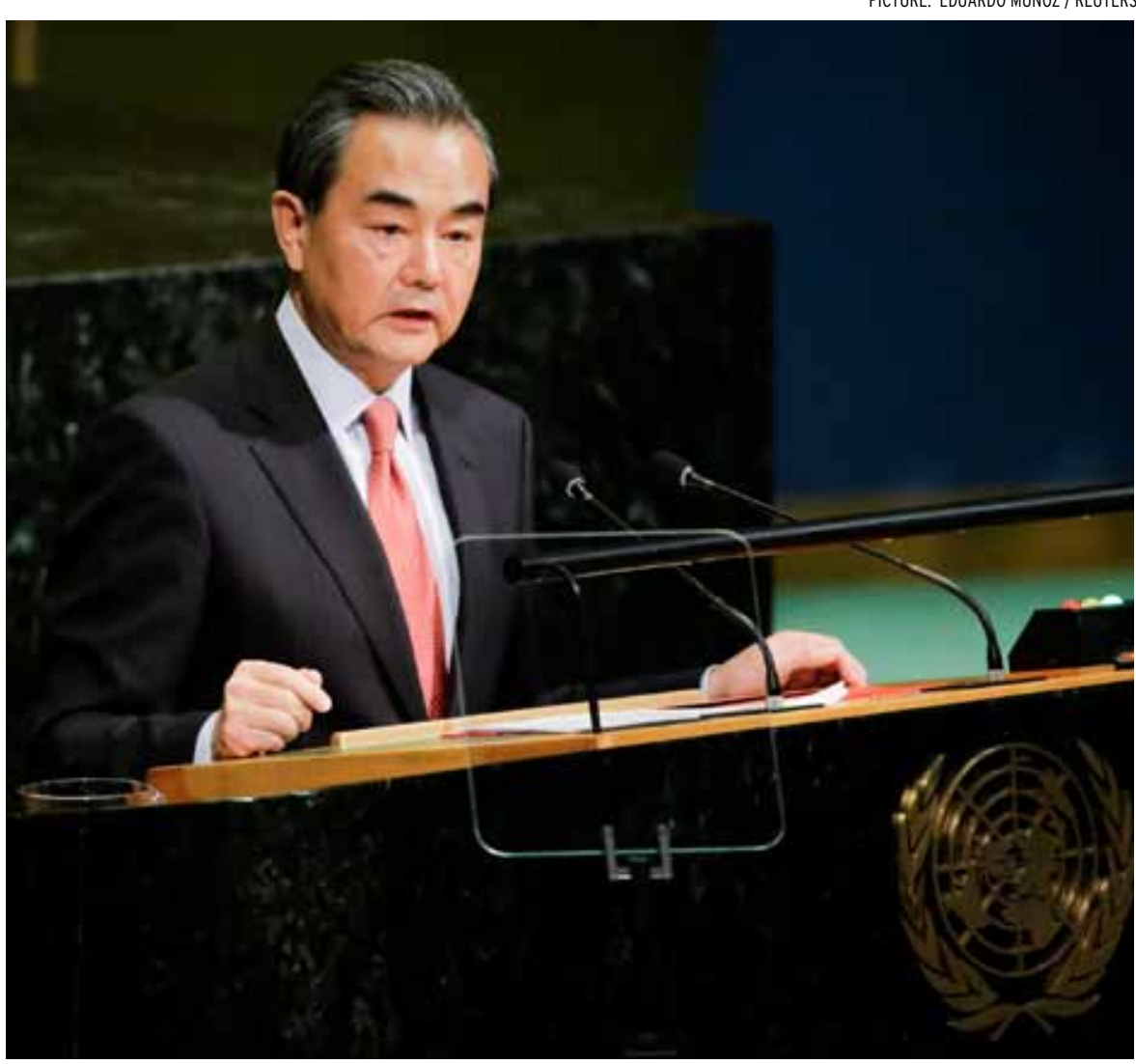

Chinese Foreign Minister Wang Yi at the UN General Assembly in September 2017. China 'often defends the more old-fashioned interpretation of sovereignty' against efforts to reinterpret the concept.

to insulate it from serious pressure via the UNHRC.

Given its diplomatic achievements in shaping the human rights regime in ways that blunt the regime's ability to embarrass or influence the Chinese regime, China does not appear to be aiming for any major changes in the regime or its abandonment.

The Law of the Sea is inherently complicated and China, like all other states, has interpreted it in its own favour. Having acceded to the UN Convention on the Law of the Sea (UNCLOS) in 1996, China has interpreted its provisions on continental shelves and exclusive economic zones to claim control over large maritime areas. It has presented claims to land forms at sea that are based on customary international law provisions such as first discovery, continued occupation, effective administration and unchallenged claims. China interprets UNCLOS provisions on 'innocent passage' as denying US navy ships and air force planes the right to conduct intelligence operations and what the United States calls 'freedom of navigation operations' in Chinese waters without Chinese permission.

On climate change, China supported the Kyoto Protocol principle and joined the 2016 Paris Climate Agreement. China has also stated it will continue to comply with the Paris Agreement despite President Donald Trump announcing US withdrawal from the agreement. Meanwhile China has moved faster on renewables than the United States, not only in response to international requirements but as part of its own energy security policy. 


\section{FALSE DICHOTOMIES}

In sum, Chinese behaviour in international regimes does not show a pattern of promoting a distinctive 'Chinese model' or an alternative vision of world order. If there is a larger pattern, it is that China tends to be a conservative power, resisting efforts by the United States and its partners to shape regimes in unfavourable ways. In its competition with the United States and its allies, China often defends the more oldfashioned interpretation of sovereignty against efforts to reinterpret sovereignty in a more limited way. China in this sense is more of a status quo power than the United States.

As long as China remains roughly in its current trajectory-politically stable with a growing economy-its stake in various international regimes is unlikely to change dramatically. If China becomes an even stronger power relative to its rivals, it is likely to bid for more influence in existing regimes rather than try to overthrow them. If it suffers economic or political setbacks, it will have less influence on the evolution of the regimes, but will hardly be able to afford to abandon them. While China will continue to influence the evolution of global norms, it is hard to imagine a realistic scenario in which it will try to revolutionise or overthrow them. EAFO

\section{Andrew J. Nathan is Professor of Political Science at Columbia University.}

This article is drawn from 'China's Rise and International Regimes: Does China Seek to Overthrow Global Norms?' in Robert S Ross and Jo Inge Bekkevold, eds., China in the Era of Xi Jinping (Washington: D.C.: Georgetown University Press, 2016), pp. 165-195; published with the permission of Georgetown University Press.

\section{Australia must move beyond 'Cold War thinking'}

\section{PETER DRYSDALE AND \\ JOHN DENTON}

S

EARCHING for evidence of Chinese influence in Australia? Look no further than the census. Around 1.2 million people declared themselves of Chinese heritage. About 600,000 were born in mainland China. And while recent coverage of alleged Chinese 'influence' in Australian politics might have you think otherwise, the Australian-Chinese community isn't a dagger pointed at the heart of Australian democracyit's a diverse community with every right to participate in the political process.

There are also more than 170,000 Chinese nationals at our universities. The overwhelming majority come at their families' expense to buy an Australian education.

There's a narrative that would have you think that a shadowy cabal of Chinese-born businesspeople is trying to control national policy with cash and that Chinese students are bent on overthrowing our institutions, freedoms and rights. It's an insinuation without foundation. The evidence for it is scant. When offences occur, they should be addressed through Australian legal and political institutions and by our universitiesnot the slander of whole classes in our community.

People of Chinese origin and Chinadomiciled businesspeople do make donations to politicians, universities and other Australian institutions, for the same reasons that other people do: to gain prestige, to establish standing, to gain access to certain social circles, or because they feel affinity with the ideas of the politicians or parties they support. Some doubtless hope to influence policy outcomes to their advantage, as do donors of all nationalities. This does not mean those hopes are realised. Nor can it be assumed that they are acting at the behest of a government agency in Beijing.

Do Chinese students bring different world views to our campuses from Australian, Indian or other foreign students? Of course they do. Some of them are actually members of the Chinese Communist Party, though the overwhelming majority are not. Most are profoundly influenced by the experience of Australian culture, society and institutions. Not all, of course, but nor are Australia's own.

So why are donors of Chinese background or students of Chinese origin being targeted now?

Importantly, there's an elevated demonising of China to quell deep and gnawing anxieties that surround the unpredictability of the US alliance under Donald Trump.

The hype also reflects shallowness in the way that some Australian commentators understand the Chinese political system and express anxieties about the directions that it might take. 
The Chinese Communist Party has 90 million members: larger than the entire population of Germany. It's ludicrous to imagine that they are all spies, or that Beijing or its United Work Front Department is capable of marshalling every single businessperson or student in foreign countries to prosecute its geopolitical agenda, even if it wanted to.

Another error that does damage to Australia's understanding of China is to buy into a false dichotomy of liberal democracy and totalitarianism. China is no Jeffersonian polity, that's for sure. And the political system appears to be regressing on the freedom index. But nor is it North Korea. No knowledgeable person would think there's political equivalence between them. Democratic norms aren't entrenched in China and the country is a singleparty state under change, but we recognise the state and its institutions and sensibly encourage Chinese long-haul ambitions to improve them.

Different systems don't prevent close ties between Australia and Singapore, or Australia and Thailand. Differences with China's system are of another order. But, in areas like global trade and climate change, Beijing is becoming a critical defender of the rules-based order on which we rely for economic and political security. Their systems differ profoundly, but Australia and China have significant common cause and goals.

Does the Chinese government have perspectives about China's interests that it promotes abroad? Of course, and when they differ from Australia's, there's every reason to make Australia's positions clear.

W HAT might prevent close ties between Australia and China from delivering their economic and political benefits, with heavy consequences, is failure to do the thinking needed about managing the relationship. Mutual trust on key issues is attainable as long as a framework of engagement exists for continued dialogue-and as long as Australia can engage in debate based on facts rather than false logic and association. To act otherwise does no credit to confidence in, and loyalty to, our national values and institutions.

China is set to remove many of the restrictions on where and how its citizens can save and invest. This will reshape the world's financial landscape, driving change in political behaviour in China itself. For Australia, it will mean financial inflows that lift business investment and underwrite nation-building infrastructure. The interaction between Chinese students and Australian classmates creates essential connections and invaluable assets as the two economies become more interdependent.

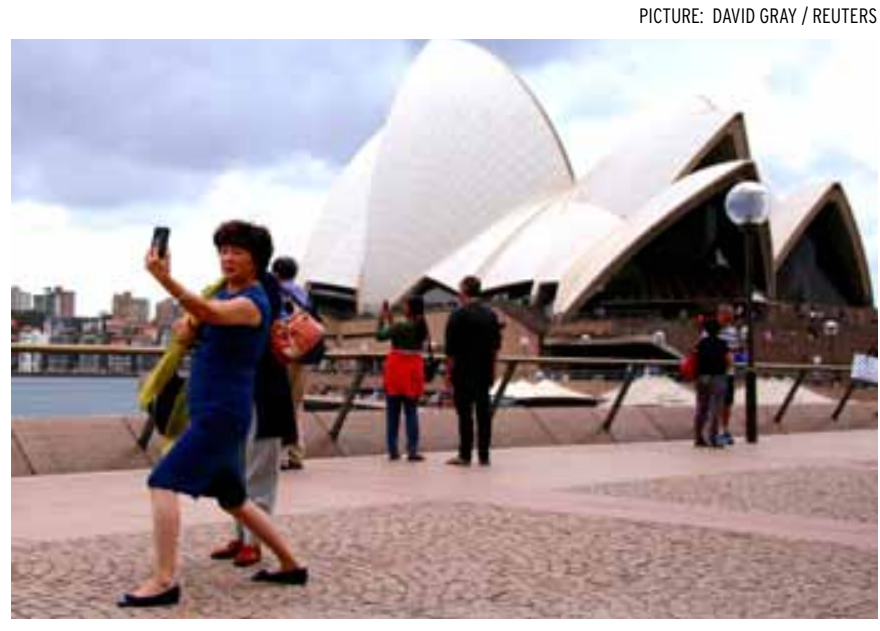

A Chinese tourist takes a selfie at the Sydney Opera House in March 2017: closer ties with China carry economic benefits for Australia.

$\mathbf{T}$ HESE opportunities will be squandered if Australian policy towards China is bungled. Policies must give Chinese investors confidence in being treated fairly, not scapegoated for what are the failures of Australian policymaking rather than malevolent foreign influence.

Australia's political institutions and universities are strong. They can engage the rest of the world confident that their integrity is robust and safe.

Political donations in Australia should be more tightly regulated to prevent being their being used to curry favour improperly or distort policymaking processes. If rules are tightened, they should be tightened for everyone equally. Don't blame one ethnic community or foreign country for a phenomenon that is not unique to it.

Australia's universities are respected for safeguarding traditions of academic freedom and impartial inquiryfrom governments of all kinds.

As a nation we rejected McCarthyism when we rejected the Anti-Communist Party Dissolution Bill in 1951. That protected Australians' right to be members of the Australian Communist Party, which in good time disappeared.

Australians future prosperity and security depends on rejecting simple Cold War thinking, and they need to start on the large but necessary task of building a knowing but constructive, trust-based relationship with China. EAFQ

\section{Peter Drysdale is Emeritus Professor at The Australian National University, Director of the East Asian Bureau of Economic Research and Co-editor of East Asia Forum.}

John Denton is CEO of Corrs Chambers Westgarth and First Vice-Chairman of the International Chamber of Commerce. 


\section{Does Japan need the Pax Americana?}

\section{RICHARD MCGREGOR}

N STAGE with Prime Minister Shinzo Abe during his visit to Japan in early November, Donald Trump struck an all-too-familiar crass tone as he attempted to sum up the economic relationship between the United States and his host country: 'I don't know if [your economy] is as good as ours. I think not... We're going to try to keep it that way. And you'll be second?

Trump was trying to make a genuine point, underscoring his complaint that the United States has long had a trade deficit with Japan, and Trump believed that this needed to change.

But Trump struck a decidedly different note on security. Talking up the military alliance between the two countries, he suggested that ties would become more robust given the immediate threat from North Korea and the long-term rise of China.

There is little doubt that security ties between the United States and
Japan are closer now than at any time since the early 1950s. It is not just the greater ability of their two militaries and their systems to work together. The biggest change has been in Japanese politics, the most notable aspect of which is Abe's success at forcing through revision of security laws to rid Tokyo of many of the shackles that have tied its military down for so long.

After an overwhelming election victory in October, Abe is now aiming to rid Japan of certain articles of the

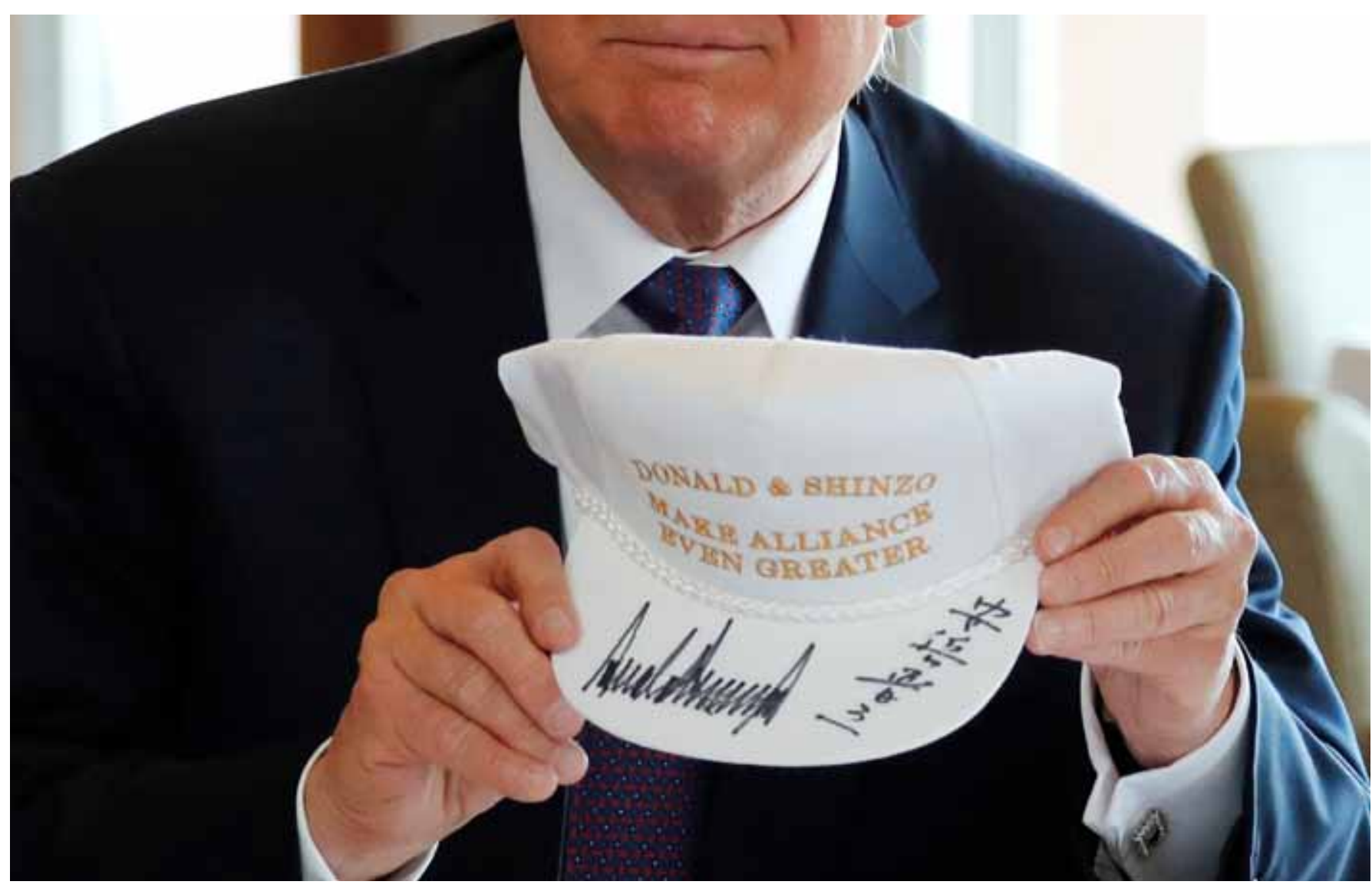

US President Donald Trump with a cap he signed with Japanese Prime Minister Shinzo Abe in November 2017. The headwear celebrates the nations' alliance. 
constitution. His aim is to transform Japan's self-defence forces into a conventional military.

For news out of East Asia, it is difficult to compete with North Korea's youthful and jocular despot, Kim Jongun, and with and his near-daily threats to fire nuclear-tipped missiles at US territory. Lost among the headlines is the fact that the crisis is just a symptom of a bigger drama unfolding in East Asia: the entire postwar order that has been built and maintained by the United States since 1945 is slowly coming apart.

For the past seven decades the Pax Americana underwrote an explosion in wealth not matched in the world since the industrial revolution. Since the 1950s, Japan, South Korea, Taiwan and China have been able to put aside bitter political and historical enmities to pursue economic growth.

At the same time, the US presence in East Asia has papered over serial diplomatic failures. All of the 1950s conflicts that were buried during the decades of high-speed economic growth are starting to resurface. China and Taiwan have drifted further apart than ever. The Korean peninsula remains divided and is bristling with both conventional and nuclear armoury. The China-Japan rivalry overflows with bitterness despite a bilateral business relationship that is one of the most valuable in the world.

Whether these tensions play out peacefully depends not just on the United States and China. Japanwhich has at different times threatened to eclipse them both-is also pivotal to regional stability.

During the presidential campaign, Trump suggested that Japan and South Korea had become over-reliant on US security, and that it was time for the United States to pack up and go home. But Asia's economic rise has only magnified the dangers of a US drawdown.

Sheltering under the United States' nuclear umbrella during the post-war period, Japan has been a constrained power since its defeat in 1945 . Japan, at least in security terms, has at times seemed happy to play an 'inert' role, and has been willing to free-ride on the United States and focus on its own economic development.

But those days are over. While attention was focused on Pyongyang's nuclear antics in early August, Japan quietly announced that it was busy studying how to equip its military with offensive weapons that would allow it to strike overseas enemies for the first time since the war.

Japan presents a particular challenge to China. Militarily, it is not a pushover.

In 2012, the central government in Tokyo nationalised the Senkaku/ Diaoyu Islands in order to prevent a far right-wing nationalist politician from buying them from their private owners. Beijing then considered trying to take the islands by force. A retired regional leader with good connections in both China and Japan recently reflected to me that Beijing had studied its options carefully: 'They did a number of basic tabletop exercises to work out, if there was a conflict over the islands, whether China could

\section{Japan knows that China}

$$
\text { is not going away. One }
$$

\section{day, the United States}

\section{might}

prevail'. In the end, he said, Beijing concluded that the 'co-relation of forces was not with them'. Unlike Japan, which has fought naval wars, China has fought only one (in 189495) which it lost. The Chinese had made huge strides as a military power, but were still unsure about taking on their old foe.

Perhaps the most salient factor in China's calculations over the Senkaku/ Diaoyu Islands was what might happen if it should lose to Japan. In Tokyo, a military loss would be disastrous, and the government would certainly fall. But that would be nothing compared to the hammer blow to China's national psyche should Japan prevail. 'That would be terminal for the CCP', the former regional leader observed. 'Regime change.'

Japan knows that China is not going away. One day, the United States might. China is keen to emphasise to every nation in Asia a single truth: China's presence is a geopolitical reality in Asia. By contrast, the US presence is a geopolitical choice, and it is one that China intends to make more and more costly.

The institutional ties between the United States and Japan remain strong and deep. For the moment, Abe's artful diplomacy and flattery of Trump has restored an equilibrium in top-level relations as well. But if Tokyo continues to feel threatened and loses faith in the United States, the next step is going nuclear-a policy that is now discussed openly in Japan. That will be the definitive sign that Pax Americana in Asia is over, and it could come sooner than anyone thinks. EAFQ

\section{Richard McGregor is a Washington- based author and journalist. His latest book is Asia's Reckoning: China, Japan and the Fate of US Power in the Pacific Century.}




\section{Party control of state-owned enterprises}

\section{KJELD ERIK BRøDSGAARD}

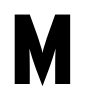

$\mathrm{UCH}$ has been written on the need for reform of China's state-owned enterprises (SOEs). They play an important role in the Chinese economy, dominating China's strategic sectors and pillar industries. They are also key instruments for the implementation of Chinese Communist Party (CCP) policies and strategic initiatives. But in terms of return on assets they are widely regarded as less profitable than privately owned companies.

For years, concomitant with the development of the market, substantial reform of SOEs has been announced. The movement towards SOE reform reached a high point in November 2013, when the Third Plenary Session of the 18th Central Committee adopted a comprehensive reform program that contained a key section on SOE reform.

But since then reform within this area has stalled and even gone backwards. Instead of being divided into smaller, mutually competitive companies, China's large SOEs have experienced a process of consolidation that has created even bigger companies.

$\mathrm{Xi}$ Jinping's recent report to the 19th Party Congress contains only a brief paragraph on SOE reform. The absence of directives from $\mathrm{Xi}$ on this front reinforces the impression that plans for further reform and liberalisation have been shelved and replaced with a renewed focus on centralisation and control in the hands

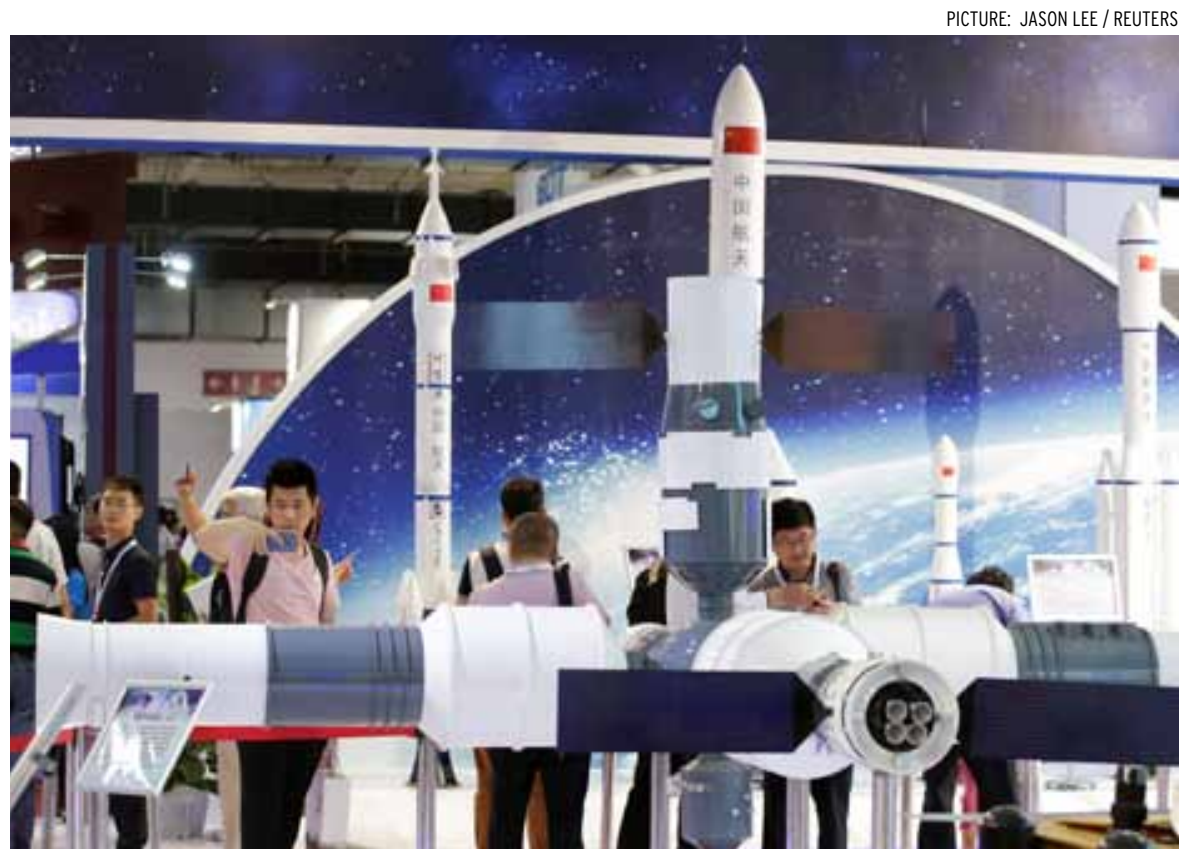

Visitors at the China Aerospace and Technology booth at the China Beijing International High-Tech Expo in June 2017. Aerospace is one of the strategic sectors where the party is keen to maintain control.

of the CCP.

Following former Chinese premier Zhu Rongji's period of SOE reform from 1997-98, many of China's large SOEs grew into huge and diversified enterprises with significant economic and political clout. They accumulated enormous financial resources and many posted enormous profits. The executive elite in charge of these enterprises had vice-ministerial status and often outranked the state administrative organs and bureaus that were supposed to regulate them. The considerable autonomy of these SOEs has contributed to an increasingly fragmented political-economic order in China.

In terms of foreign policy, the SOEs' growing role and influence in Africa, Latin America and other overseas markets has also contributed to fragmented policymaking. Studies of Chinese oil companies show that, on occasion, they pursued interests and polices that were not in alignment with the Chinese state. In the case of Sudan, for example, the Chinese Ministry of Commerce had to issue regulations limiting the activities of the China National Petroleum Corporation in order to better promote China's image as a 'responsible stakeholder'.

There have always existed forces of integration moderating the trend towards SOE fragmentation. The most important of these is the CCP's control of Chinese SOEs.

The party controls SOEs in various ways. All enterprises must have a party organisation headed by a party secretary. Recent party documents 
stipulate that all important decisions must first be studied and discussed by the party committee of the enterprise. Only after that committee has forwarded a recommendation can the matter be decided by the board and an action implemented. This ensures that the CCP has a decisive say on enterprise operation and management.

It is also stipulated that in enterprises where a board has been established, the party secretary and chairman of the board must be the same person. Members of the company's party committee should also serve on the board of directors, management team and supervisory board.

This principle of overlapping positions and cross appointments has been at the centre of recent discussions on enterprise management in Chinese media. The former chairman of the State Council's State-Owned Assets Supervision and Administration Commission (SASAC), Li Rongrong, praised the crossappointment system as an 'effective measure to combine corporate governance with the party, which is the political core of the company'

Since 2015, cross appointment has become a key concept in the party's management of stateowned businesses and government institutions. Former leader Deng Xiaoping's policy of separating party and government has been officially abandoned and the notion of separating government and business has also largely disappeared from public discourse.

The party is especially keen on maintaining control over the SOEs managed by SASAC. They are the largest Chinese enterprises in terms of revenue and employment, accounting for most of the Chinese companies on the Fortune Global 500 list of the world's largest companies. These SOEs-often called China's 'national champions'-dominate the strategic sectors of the Chinese economy, such as aerospace, telecom, power generation, automaking and shipbuilding. The leaders of the 53 largest are not appointed by SASAC, but rather by the party's Organisation Department. They are part of the party's nomenklatura system and are cadres ranked at vice-ministerial level. This means many business executives are subject to cadre rotation and are moved to take up government or party positions.

Examples of such rotation are legion. Zhang Guoqing served as general manager of China North Industries Group before being moved to Chongqing in 2013 to take up the position of vice mayor. Recently he replaced Huang Qifan as mayor and deputy party secretary of Chongqing.

The former general manager of China Aerospace Science and Technology Corporation, Ma Xingrui, was appointed vice minister of Industry and Information in early 2013. A few months later he was transferred to Guangdong to become deputy party secretary. In December 2016 he was appointed governor of the province.

Zhang Qingwei is an example of an executive who has moved

\section{... the notion of}

\section{separating government}

$$
\begin{aligned}
& \text { and business has largely } \\
& \text { disappeared from public }
\end{aligned}
$$

discourse back and forth between business, government and the party. He was general manager of China Aerospace Science and Technology Corporation from 2001-07 but was transferred to government work in the fall of 2007 to become minister of the Commission for Science, Technology and Industry for National Defense. When this ministry was merged with the Ministry of Industry and Information in 2008, Zhang Qingwei was transferred back to business to head China Commercial Aircraft Corporation. In 2011 he was moved back to government work to become vice governor and later governor of Hebei province, and in the summer of 2017 he was promoted to party secretary of Heilongjiang province.

The nomenklatura system and cadre rotation are powerful instruments in the hands of the party-state.

The renewed emphasis on cross appointment and on the role of party organisations in SOEs indicate that the CCP's current policy is to strengthen rather than weaken its control over SOEs.

Xi Jinping's report to the 19th Party Congress strongly emphasised the party's ubiquitous presence in Chinese society and economy. Thus forces of integration and control, including the business-party-government 'iron triangle', moderate a trend towards fragmentation of the Chinese polity, creating a uniquely hybrid form of integrated and centralised fragmentation. EAFQ

Kjeld Erik Brødsgaard is Professor of China Studies at the Department of International Economics and Management and Director of the China Policy Program, the Copenhagen Business School. His latest publication is Critical Readings on the Chinese Communist Party (2017). 


\section{ASIAN REVIEW: OLD DOMINANCE AND NEW DOMINOS}

PICTURE: SOE ZEYA TUN / REUTERS

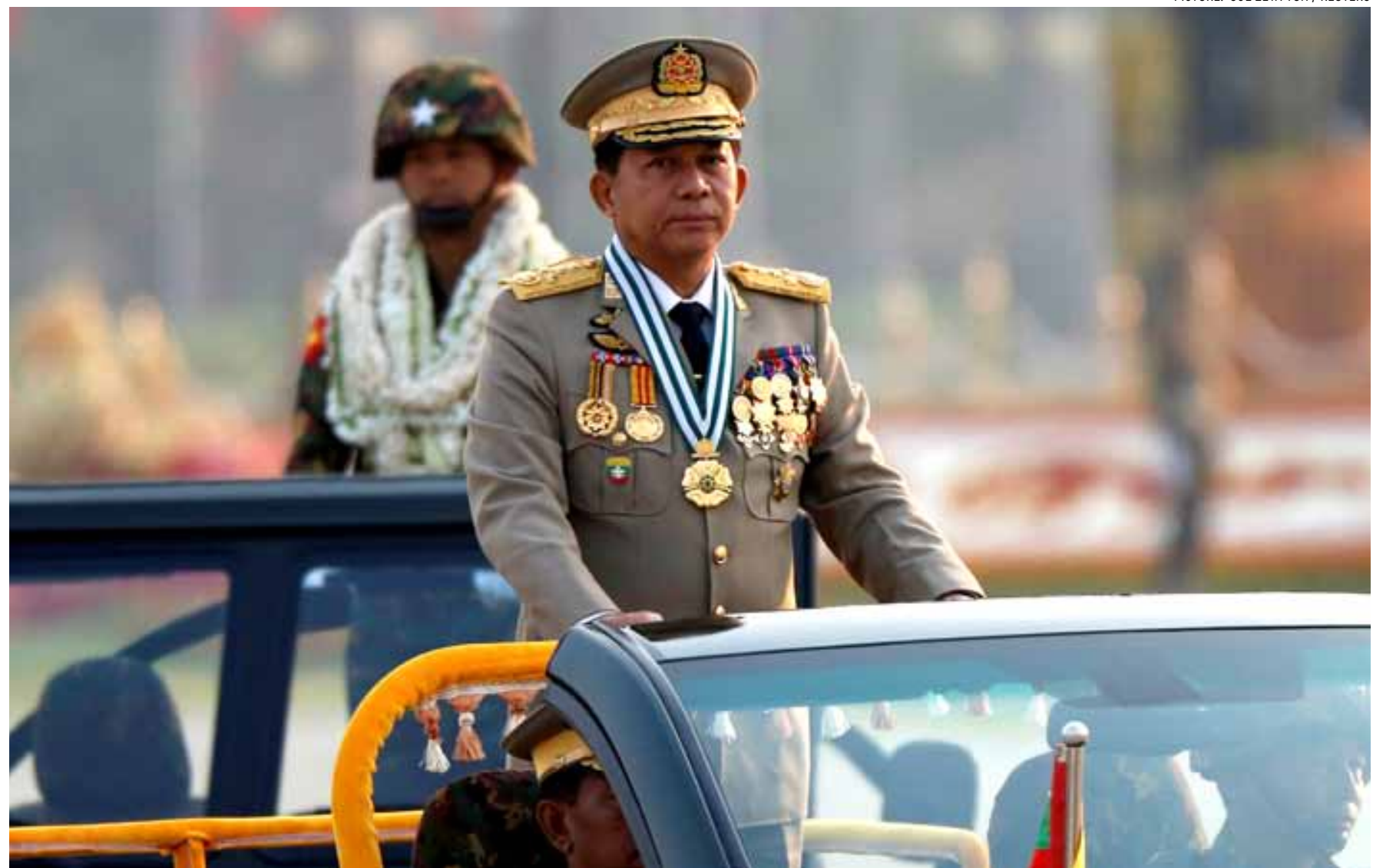

General Min Aung Hlaing, commander in chief of Myanmar's military, in the parade in Naypyitaw to mark the 72nd Armed Forces Day on 27 March 2017 . Myanmar has moved in a more democratic direction since 2011, but the 'ideological potency of ethnic and religious nationalism' explains why minorities are brutalised.

\section{Dark days for democracy in Southeast Asia}

\section{DAN SLATER}

N

OT since World War II has liberal democracy seemed so deeply endangered in so many places at once. For the first time in threequarters of a century, illiberalism and chauvinism have stolen the march, virtually all over the globe, on their liberal and cosmopolitan rivals.

With narrow voices for exclusion and nativism making frightening headway against broader visions of inclusion and diversity in Britain, France, Germany, Hungary, India, Poland, South Africa, Turkey and the United States, it seems fair to conclude that they can now gain important ground just about anywhere at any time.

If the flu of political and social illiberalism is circumnavigating the globe, Southeast Asia has precious little immunity with which to withstand it. This is a region where authoritarian regimes have always easily outnumbered democracies, and where liberalism and universalism have always struggled to gain traction against religion, nationalism and communalism as forms of ideology and identification. So it should be no surprise that in a historical moment when democracy feels unsafe even in formerly safe-seeming spaces, it feels in Southeast Asia as if democracy could readily be extinguished entirely.

It wouldn't be the first time since decolonisation that Southeast Asia 


\section{ASIAN REVIEW: OLD DOMINANCE AND NEW DOMINOS}

suffered a complete democratic wipe-out. Historically speaking, the region's democratic nadir ran from the early 1970s, when Malaysia's Barisan Nasional (BN) and the Philippines' Ferdinand Marcos converted their electoral legitimacy into outright authoritarian power, until the mid1980s. For most of that decade and a half, Southeast Asia had literally no regime that met even minimally democratic standards-with the minor exceptions of Thailand's fleeting democratic experiment during 1973-76 and grudging democratic opening over the course of the mid to late 1980s.

The Cold War did not produce the dominos of successive collapse from capitalism to communism across Southeast Asia that American interventionists feared, at least outside of what was formerly French Indochina. What it did help produce, though, was a region-wide domino effect of democratic collapses into authoritarianism.

Could Southeast Asia fall into a 1970s-style democratic abyss again? Since most of the region is enduringly authoritarian to begin with, it is already-and always-most of the way there. As in the early 1970s, the global outlook for democracy seems bleak. External contributions to democratisation in Southeast Asia should never be overstated, of course. But whether by coincidence or not, democracies in Southeast Asia-as well as Northeast Asia-have almost always either been cosy or trying to get cosier to the United States.

If the gravitational pull of American democracy has ever really reached all the way to Southeast Asia, it has changed from attraction to repulsion almost overnight with the presidential ascendancy of Donald Trump.

One could have recently imagined, for example, Vietnam following the path of Taiwan by responding to an increasingly threatening and intrusive China by burnishing its democratic credentials as a down-payment on a stronger American alliance. If Hanoi wants better ties with Washington now, it would be best advised to start building the right brand of luxury hotels rather than the right kind of political regime.

Even before these disturbing global authoritarian trends emerged, Southeast Asia displayed a dismal democratic baseline. We would do well to distinguish the cases of existing dominance that establish that dismal baseline from what we might call the new dominos, which find themselves either tumbling or looking increasingly wobbly.

None of the region's long-dominant authoritarian regimes appear deeply endangered at the moment. Singapore's People's Action Party is riding high in the saddle after its most recent electoral-authoritarian landslide. It remains disinclined to promote political liberalisation despite the manifest lack of risk to its own dominance from doing so. The gossipy drama of the Lee family feud distracts from the deeper point that an honest and independent media outlet could never get a licence to investigate and

\section{Dictatorships ruled by}

parties have long tended

to be more stable than

those in which the military

plays the leading role report on it freely and openly.

In Malaysia, venality is up far more than brutality is down. So long as the ruling $\mathrm{BN}$ can compensate for its high-level corruption with highlevel repression-especially by reimprisoning opposition leader Anwar Ibrahim-it seems likely to get away with it.

Commentators commonly fret that Hun Sen just killed the last remnants of democracy in Cambodia when he shuttered the Cambodia Daily and moved to ban the country's only major opposition party. But what is really transpiring is a transition from multiparty authoritarianism to single-party authoritarianism, since Cambodia has not met even minimal democratic standards for the past 25 years.

Speaking of single-party dictatorships, Vietnam's leaders have recently stepped up repression of dissidents. But it is not as if the Vietnamese Communist Party ever brooked serious dissent in the first place.

Not coincidentally, in all four cases, old dominance is rooted in old authoritarian ruling parties. In this sense, Southeast Asia is far from unique. Dictatorships ruled by parties have long tended to be more stable than those in which the military plays the leading role. So it stands to reason that the greatest action in the region, not just now but over the past decade, has been in countries where the military either still is, or in the past was, a leading power in political life. A militarised past means a high potential for a dominoing present.

Just as we can identify four clear cases of old dominance rooted in authoritarian ruling partiesCambodia, Malaysia, Singapore, and Vietnam-four cases fit more readily in the new domino category: 


\section{ASIAN REVIEW: OLD DOMINANCE AND NEW DOMINOS}

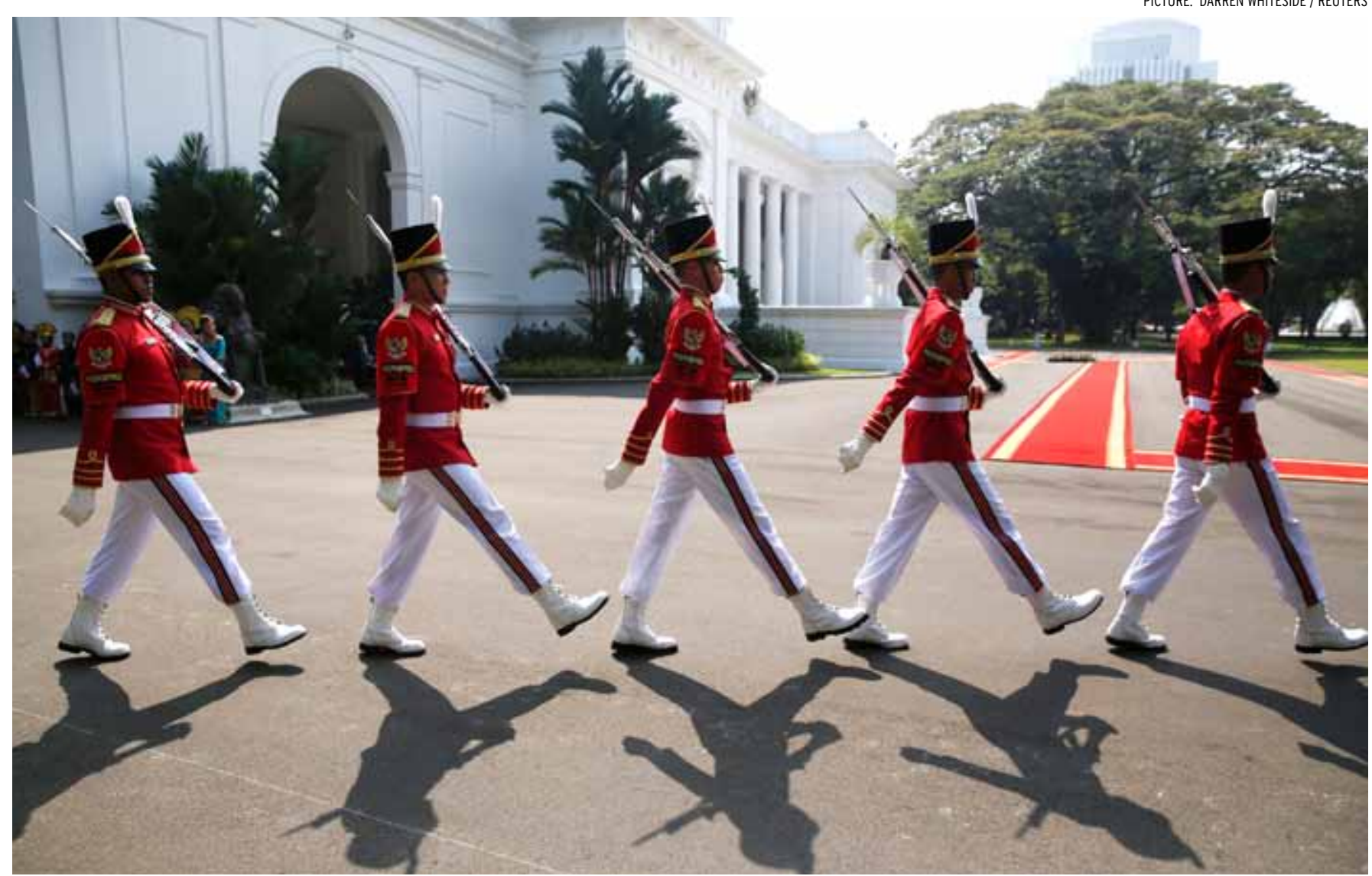

A military honour guard at the presidential palace in Jakarta: political parties' failure to supersede the power of the military has weakened democracy.

Indonesia, Myanmar, the Philippines and Thailand. In each case, there is a long history of parties failing to decisively supersede the power of the military, which left their democracies with relatively little institutional strength to sustain themselves. In the case of Thailand, these weak civilian institutions have already laid the groundwork for outright democratic collapse at the military's-and monarchy's - hands.

Even among these latter four cases, the story in terms of national regime type has been one of stability far more than instability. Of the eight Southeast Asian cases discussed here, only in Myanmar and Thailand have outright regime transitions occurred since the turn of the millennium. And one of the two, Myanmar, has moved in a more democratic direction since 2011. So it is worth stressing that Southeast Asian democracy has not exactly been cratering.

But the times and the tides seem to be turning. Could Myanmar soon follow Thailand's recent path back to unchallenged military rule? Could the Philippines, now ruled by a strongman backed by martial law in Mindanao, descend from its current fragile status as an illiberal democracy to an outright one-man dictatorship? And does the shocking imprisonment of Jakarta's ethnic Chinese former governor on blasphemy charges portend the demise in Indonesia of the tolerant norms on which even a minimalist democracy depends?

Although all four of these countries have been travelling in different downward trajectories, there is a vital common theme. When procedural democracy arises in otherwise politically and socially illiberal and intolerant conditions, democracy's own key features can easily - and ironically-undermine its own quality and even threaten its own survival.

Specifically, democratic procedures have a tendency to produce unbridled majoritarianism and unconstrained leadership unless there are powerful countervailing forces to contain them. In settings where liberal institutions and societal commitment to inclusive and cosmopolitan values are relatively weak, minorities exist at the mercy of majorities. Sometimes that minority is defined demographically; at other times it is established electorally.

The Philippines and Thailand both exemplify the dangers of domineering and abusive executives in illiberal democratic settings. Empowered and 


\section{ASIAN REVIEW: OLD DOMINANCE AND NEW DOMINOS}

emboldened by decisive electoral majorities, Thaksin Shinawatra attempted and Rodrigo Duterte is now attempting to overcome legacies of unresponsive, oligarchic politics in both countries through force of personal will.

In Thailand this did not lead to outright populist authoritarianism, in part because the Thai military and monarchy saw fit to re-establish oligarchic authoritarianism instead. It is in the Philippines where a brazenly violent populist seems inclined to seize as many authoritarian-style powers as the system and public will allow. As abysmal as Duterte has been for human rights, his defenders quite plausibly prefer a highly popular president responding to actual social ills like the drug trade over a discredited leader hanging on through electoral malfeasance, as Gloria Macapagal-Arroyo did a decade ago.

Human rights conditions are sliding downhill in Indonesia and Myanmar as well. In Indonesia both anti-communist and anti-Chinese sentiment have made frightening comebacks from their Cold War demises. Since these were the same fear-filled mentalities that spawned and sustained Suharto's New Order, their re-emergence suddenly makes democracy feel unsafe again at the national level.

Conditions in transitional Myanmar are of course immeasurably more dire. But democratisation does not deserve the brunt of the blame for an ongoing calamity like the forcible expulsion and-why split hairs? - the state-sanctioned mass murder of the Rohingya.

In Myanmar as in Indonesia, it is the ideological potency of ethnic and religious nationalism that explains why minorities get brutalised. Narrowly defined nationalism is
Narrowly defined

\section{nationalism is one of the}

most dangerous gateways

\section{to authoritarianism,}

\section{as well as a force that}

\section{undermines democratic}

\section{substance}

one of the most dangerous gateways to authoritarianism, as well as a force that undermines democratic substance. Democracy may embolden an electorally supercharged ethnic or religious majority to believe it can do whatever it wants with unvalued minorities. But it is authoritarian legacies of militarisation in Myanmar, and ethnic and ideological scapegoating in Indonesia, that best explain the severity and ugliness of both countries' nativist downturns.

If one vivid lesson shines through the dim shadows of Southeast Asia's democratic downslide, it is that democratisation and human rights are far from the same thing. Especially when a country's citizenry is more deeply steeped in religious than in liberal educational institutions, they will quite understandably tend to see the world in terms of good people and bad people.

Meanwhile, nationalists steeped in a lifetime of authoritarian state propaganda are analogously primed to see the world in terms of us, who belong, and them, who do not. Under such conditions, democratic rights may get extended; but no further than the ranks of the supposedly virtuous.
What all this suggests is that our global crisis of liberalism and democracy is first and foremost a crisis of education. Heroic histories of mass urban mobilisation to topple dictatorships naturally lead us to expect that if civil society is to help forge democracy, it will be by organising the resistance: 'people power', as we like to say.

This may still be largely true in Southeast Asia's cases of old dominance, where dictatorship must somehow be dislodged before democracy can be defended. But in Southeast Asia's new dominos, as in Western democracies where pluralism is under assault, a deeper educational imperative underlies the organisational challenge confronting us.

Remarkably, we have reached a moment when our politics most urgently needs to be driven not by an exalted desire to maximise human freedom, but by the base yet pressing need to minimise human cruelty. And if educational institutions - with a big help from the mass media-do not spread the message that even the lives of minorities and suspected criminals have value and are worthy of protection, who will?

For civil society to help save Southeast Asian democracy-or democracy anywhere in these dark days - its educational mission will need to loom as large as its organisational one. EAFQ

Dan Slater is Professor of Political Science and incoming Director of the Weiser Center for Emerging Democracies at the University of Michigan. This article originally appeared at New Mandala, as part of a series on the challenges facing democracy and civil society in Southeast Asia supported by the TIFA Foundation, Indonesia. 


\section{ASIAN REVIEW: REGIONAL INTEGRATION}

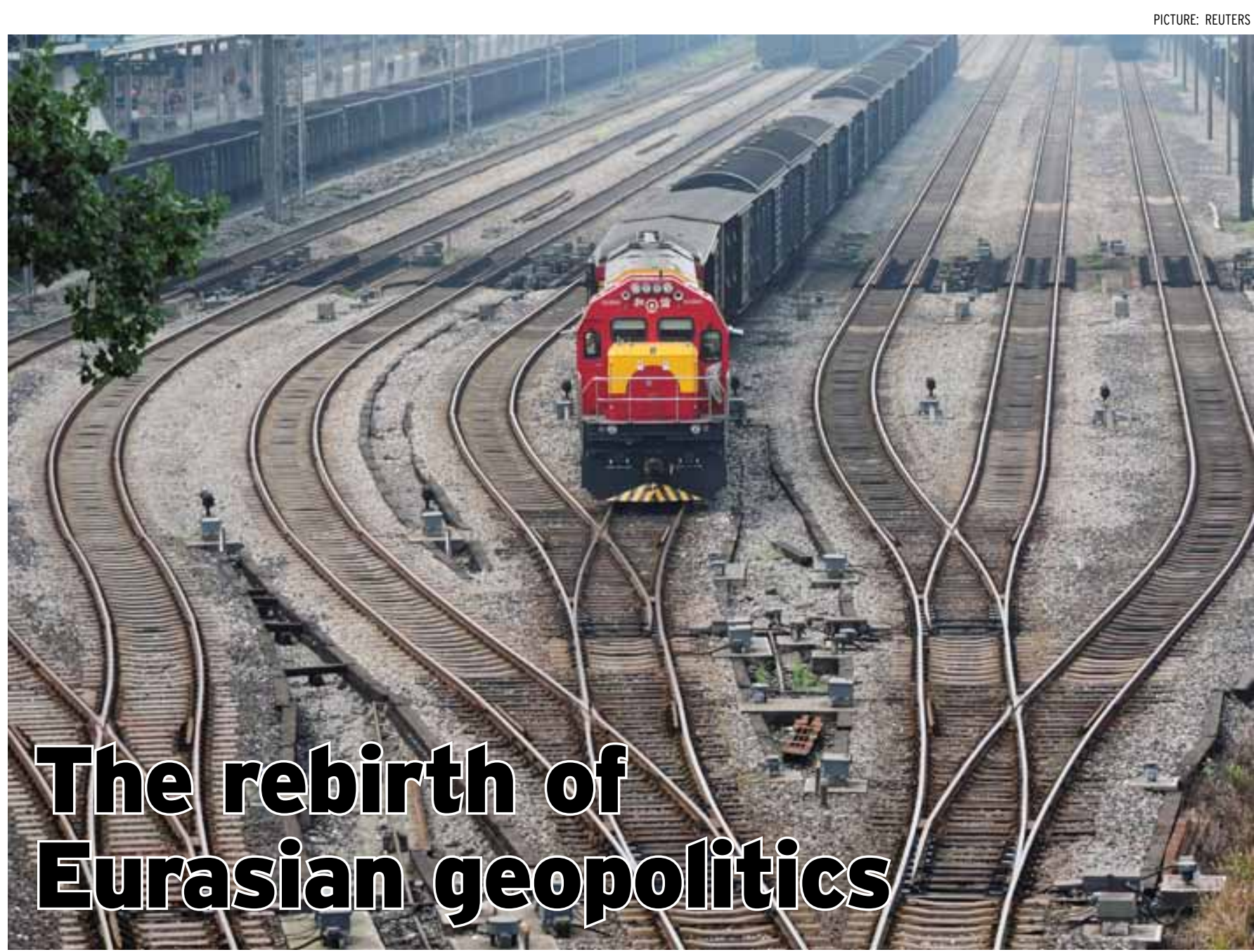

KENT E. CALDER

a OR THE first time in three quarters of a century, grand strategy is emerging as a clear-cut and central policy focus across Eurasia. US Secretary of State Rex Tillerson's recent 'Indo-Pacific' address-that prefaced President Donald Trump's first Asia trip-was another important confirmation of this growing trend. The days of the Cold War, when ideology was the central feature of conflict across Eurasia and the Soviet Union was still a single bilateral adversary, are behind us. In Eurasia, geopolitics is back with a vengeance last seen in the late 19th century during the days of the Great Game.
The strategic revival of Eurasian geopolitics has clear expressions across the continent, most conspicuously in China. President Xi Jinping's Belt and Road Initiative (BRI) is shrewdly capitalising on China's geographic centrality on land. The Middle Kingdom, after all, is located at the heart of the continent, extending two thirds of the distance from the Bohai Gulf to the Strait of Hormuz. China borders 14 countries and has land-based access routes to virtually all of its neighbours. Most importantly, China is the most populous nation on earth and boasts the world's secondlargest economy.

China's geoeconomic size at the dawn of the 21st century is growing
A train that originated in Duisburg, Germany, rolls into the Dazhou yards in China in June 2017 after travelling the Chongqing-Xinjiang-Europe route. Chinese infrastructure spending on road and rail routes helps to increase the nation's leverage in world affairs.

explosively. Any ties that it nurtures with neighbours, no matter how voluntary or how mutually beneficial, have an asymmetrical character that allows Beijing to leverage its rising role in world affairs. Infrastructure spending on cross-border road and rail links further intensifies that advantage.

Japanese Prime Minister Shinzo Abe's response to China's rise was prescient geopolitically, occurring 


\section{ASIAN REVIEW: REGIONAL INTEGRATION}

seven years before Xi first expressed the idea of the BRI. Abe voiced the 'Indo-Pacific' concept early on in an address delivered to the Lok Sabha in New Delhi in 2007, during his first term as prime minister.

The Indo-Pacific, a notion that the United States has also begun to deploy, capitalises on the geopolitical commonality that Japan, the United States and India all share as maritime powers. China may have ambitions on the water, epitomised in its naval expansion and assertiveness in the South China Sea, but the United States, Japan and India share a comparative advantage on the seas and are calling upon that advantage.

In Delhi, 3800 kilometres southwest of Beijing, India's Prime Minister Modi is also thinking in geopolitical terms, thinking tinged with the geoeconomic calculations of another rising power. He subscribes to the Indo-Pacific concept and has paid homage to it with occasional diplomatic forays as far afield as Fiji. Modi also defers to geoeconomics, but gives preference to 'Neighborhood First' initiatives closer to home. India, after all, is a geopolitical island, thrusting southward to dominate the Indian Ocean, but simultaneously limited and protected in the north by the Himalayas. So it is naturally concerned about consolidating its insular neighbourhood.

Getting the Russians engaged in geopolitical games is not difficultthey have little leverage on the economic chessboard and their ideological appeal has collapsed. The Russians do have the physical size to remain a natural player, even if they have lost much of Central Asia to the Chinese. Sanctions in Europe since the 2014 annexation of Crimea have forced them to be more geopolitically active in Asia.
Moscow has copious energy resources, advanced weaponry and longstanding Cold War ties with South and Southeast Asia, North Korea, China and increasingly Japan. Vladimir Putin, with cards in his hand, has been eager to jump in with his 'Look East' policies that help offset Russia's vulnerabilities elsewhere.

The large nations of Eurasia, as well as the United States, are definitely beginning to think and act geopolitically once again after decades of ideological and economic preoccupation. Behind this strategic transition is a quiet transformation of the continent itself, with its roots in four great political earthquakescritical junctures that cut across the last two decades of the 20th century. These earthquakes-Deng Xiaoping's Four Modernisations, the Iranian Revolution, India's economic reforms and the collapse of the Soviet Unionshaped and continue to shape a more open, interactive and volatile Eurasian continent.

Before this, Eurasia had been a much more static and compartmentalised, a perversely stable continent largely insulated

Today's Eurasia is much

more economically

integrated and politically

volatile at the grassroots, with terrorism and ethnic strife easily flowing across national borders from both explosive growth and sectarian turmoil. It is the emergence since the 1980s of this increasingly interdependent Eurasian continenttogether with reactive domestic forces in the key nations - that is driving an inevitable rebirth of geostrategy.

China, so far, has been the quickest and the most astute in responding to the new Eurasia. But the other major powers are catching up. It is important for all of them to remember, in their haste to compete across an increasingly integrated region, that the world of the 21st century is neither that of the 19th nor that of the 20th. Today's Eurasia is much more economically integrated and politically volatile at the grassroots, with terrorism and ethnic strife easily flowing across national borders. Today's Eurasia has much deeper links to Europe and much greater resource needs.

The new Eurasia needs multilateral coordination mechanisms, with both regional and global scope, much more than in the days of the original Anglo-Russian Great Game more than a century ago. Geopolitics may be re-emerging as a big power concern, but geopolitics alone is not enough to assure regional and global stability. Whether rules-based systems can fill that stabilising role-in an era of populist resentment that has already claimed US Trans Pacific Partnership accession as a casualty-remains an open question. It leaves us with the BRI as a novel incentive-based structure for regional integrationthough the BRI naturally has its dissenters as well. EAFQ

Kent E. Calder is Director of the Reischauer Center for East Asian Studies at Johns Hopkins University and a former Special Advisor to the US Ambassador to Japan. 


\section{From foes to best friends: Duterte's policy switch}

\section{RENATO CRUZ DE CASTRO}

$\mathbf{F}$

\section{ORMER Philippine president} Benigno Aquino III adopted a balancing policy to respond to Chinese pressure over the two countries' territorial disputes in the South China Sea. Aquino challenged Beijing's expansionist maritime claims by building up the capabilities of the Armed Forces of the Philippines' (AFP) and redirecting its focus to territorial defence. Responding to increased Chinese naval manoeuvres and diplomatic pressure, his administration also strengthened the Philippines-US alliance by acquiring US military equipment and seeking an unequivocal security guarantee under the 1951 Mutual Defence Treaty.

This balancing policy culminated in the signing of the Enhanced Defence Cooperation Agreement (EDCA) in April 2014. It provides for the US to rotate forward-deployed forces in Philippines territory and extensive access to Philippine military facilities. The agreement was forged to constrain China strategically as it stepped up its expansionist activities in the South China Sea.

Now President Rodrigo Duterte is unravelling his predecessor's work. His goals are diametrically opposed to Aquino's, seeking to foster closer economic and diplomatic relations with China while strategically distancing the Philippines from its formal treaty ally, the United States.

After less than three months in office and following the Permanent

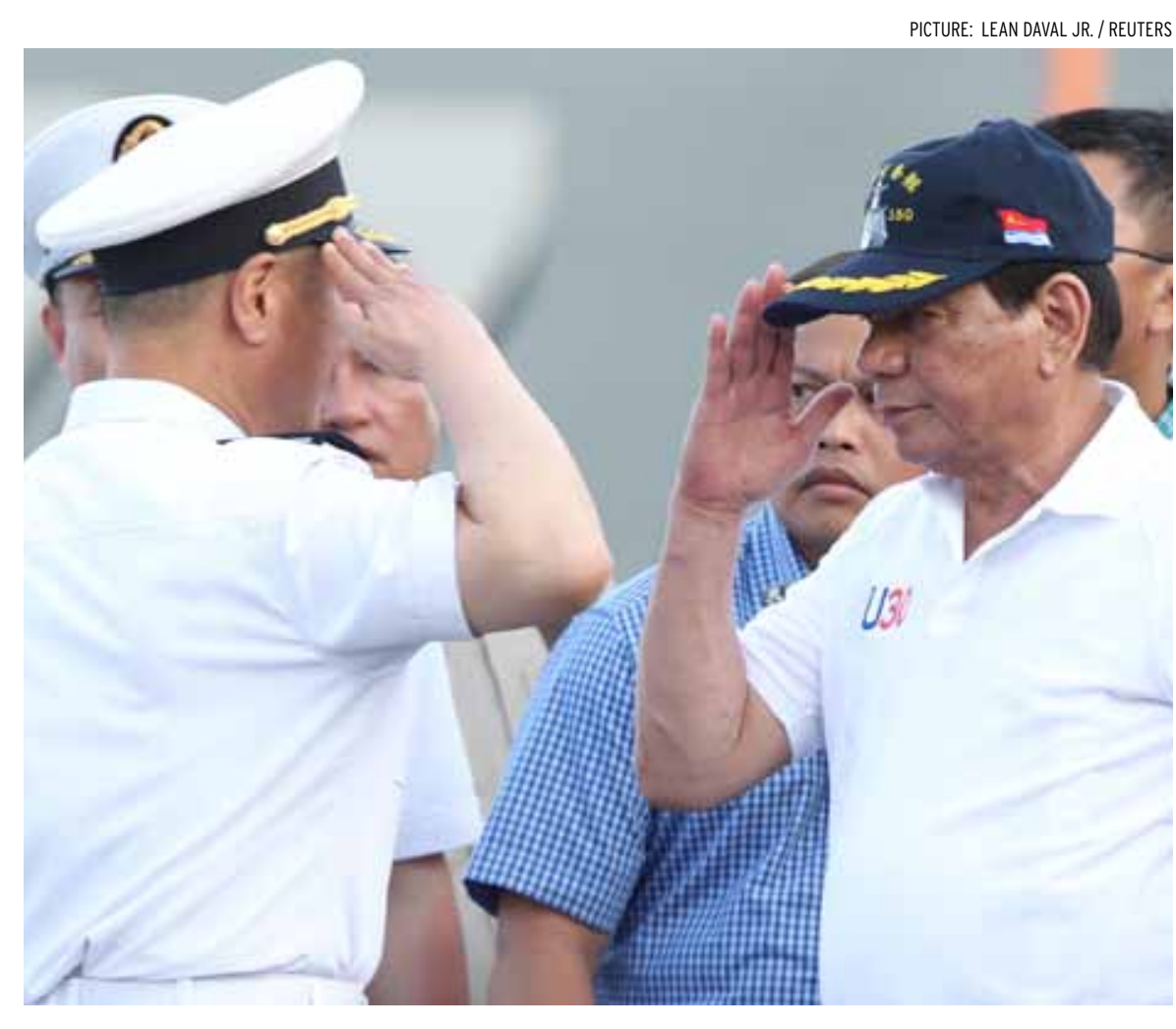

Philippine President Rodrigo Duterte returns the salute of a Chinese naval officer aboard a Chinese vessel visiting Davao City in the southern Philippines in May 2017.

Court of Arbitration's landmark ruling favouring Manila's claims against Beijing in the South China Sea, Duterte launched a diplomatic initiative to earn Chinese goodwill and confidence. At the ASEAN summit meeting in Laos in September 2016, he downplayed the maritime dispute and shortly after announced that the Philippine Navy would no longer join US Navy patrols in the disputed waters. He also called for the withdrawal of US forces supporting the Philippine Army's counterterrorism missions in Mindanao. At the same time, Duterte sought soft loans for railways in Mindanao and weapons for the Philippine military from Beijing.

In late 2016 the Duterte administration took measures to accommodate Beijing's security interests at the expense of Manila's security cooperation with Washington. In December 2016, Defence Secretary Delfin Lorenzana announced that it was unlikely that Manila would allow the US military to continue using the Philippines as a base for its freedom of navigation patrols in the South China Sea.

Duterte also announced he would not protest when it was reported 


\section{ASIAN REVIEW: SHIFTING ALLEGIANCES}

that China was installing weapons on disputed islands deep inside the Philippine exclusive economic zone. Meanwhile, former foreign secretary Perfecto Yasay Jr admitted that Manila was helpless to stop China's militarisation of the islands and later remarked that it would be beneficial for the Philippines and the United States to reassess their relationship in light of current geopolitical realities.

Clearly, he was referring to

President Duterte's earlier statement that 'China now is the power [in East Asia], and they have military superiority in the region'. Parroting China's rhetoric on the South China Sea dispute, he argued that 'the present circumstances, such as the South China Sea, may no longer require a strategy based on the old concept of the Cold War.'

But confronted by the defence department and the AFP's resistance to his policy of downgrading the US alliance, Duterte opted to continue joint Philippine-US military exercises. Duterte said his administration would use EDCA to address non-traditional security concerns like rapid response to natural calamities, while joint military exercises will not be given focus or just downgraded, at least'.

The President's objective of appeasing China at the expense of the Philippine-US alliance was evident during the annual joint USPhilippines Balikatan military exercise this year. Unlike previous Balikatan that involved massive combat drills directed at a hypothetical threat emanating from the South China Sea, this year's exercises were scaled down and focused on humanitarian, cybersecurity and counterterrorism exercises. The usually visible live-fire components were removed, while the number of Philippine and US forces involved was scaled down from 11,000 in 2016 to 5400 . Duterte's focus on non-traditional security has essentially rendered the alliance useless in constraining and deterring Chinese maritime expansion into the South China Sea.

To make matters worse, in early 2017, Duterte warned the United States that he would unilaterally terminate the EDCA in response to reports that US forces were building permanent arms depots in violation of the agreement and the Philippine constitution. Following Duterte's warning, Defence Secretary Lorenzana warned that unless the US guaranteed to support its ally, the Philippines would consider scrapping the agreement to avoid being entangled in any conflict in the South China Sea.

These developments in PhilippineChina and Philippine-US bilateral relations indicate that the Duterte administration is gravitating from a tactical to an outright or strategic appeasement of China. Duterte is determined to take advantage of China's emergence as a major economic power in East Asia and, in the process, replace Philippine-US security relations with Philippine-

Like some other East

Asian countries ...

Duterte believes that

the Philippines does not

have the capabilities to

challenge China in the

South China Sea dispute
China economic ties as the country's most important bilateral relationship.

Like some other East Asian countries, Cambodia, Laos and Myanmar among them, Duterte believes that the Philippines does not have the capabilities to challenge China in the South China Sea dispute. He has also spoken more critically about the United States, doubting Washington's willingness to back the Philippines militarily in any future confrontation with China. For him, the only option is to foster economic interdependence with China to reduce the likelihood of armed confrontation.

This means that the Philippines will lose a significant common interest with its ally, which is bent on constraining China's maritime expansion into the South China Sea. This generates major stress in in the Philippine-US security relationship that has potential to unravel the alliance in the near future.

The Duterte administration's policy on China stems from its calculation that the United States will not automatically assist the Philippines in the case of an armed conflict with China and that geography dictates that the country has no choice but to coexist and even cooperate with its powerful neighbour for economic gain. Duterte's China strategy is perceived to expand Chinese clout in Southeast Asia and might convince other Southeast Asian claimant states to negotiate directly with China to manage or eventually resolve territorial rows. And Washington's status and influence may wane in maritime Southeast Asia. EAFQ

Renato Cruz De Castro is Professor in the International Studies Department, De La Salle University, Manila and holds the Charles Lui Chi Keung Professorial Chair in China Studies. 


\section{ASIAN REVIEW: DEFENDING GLOBALISATION}

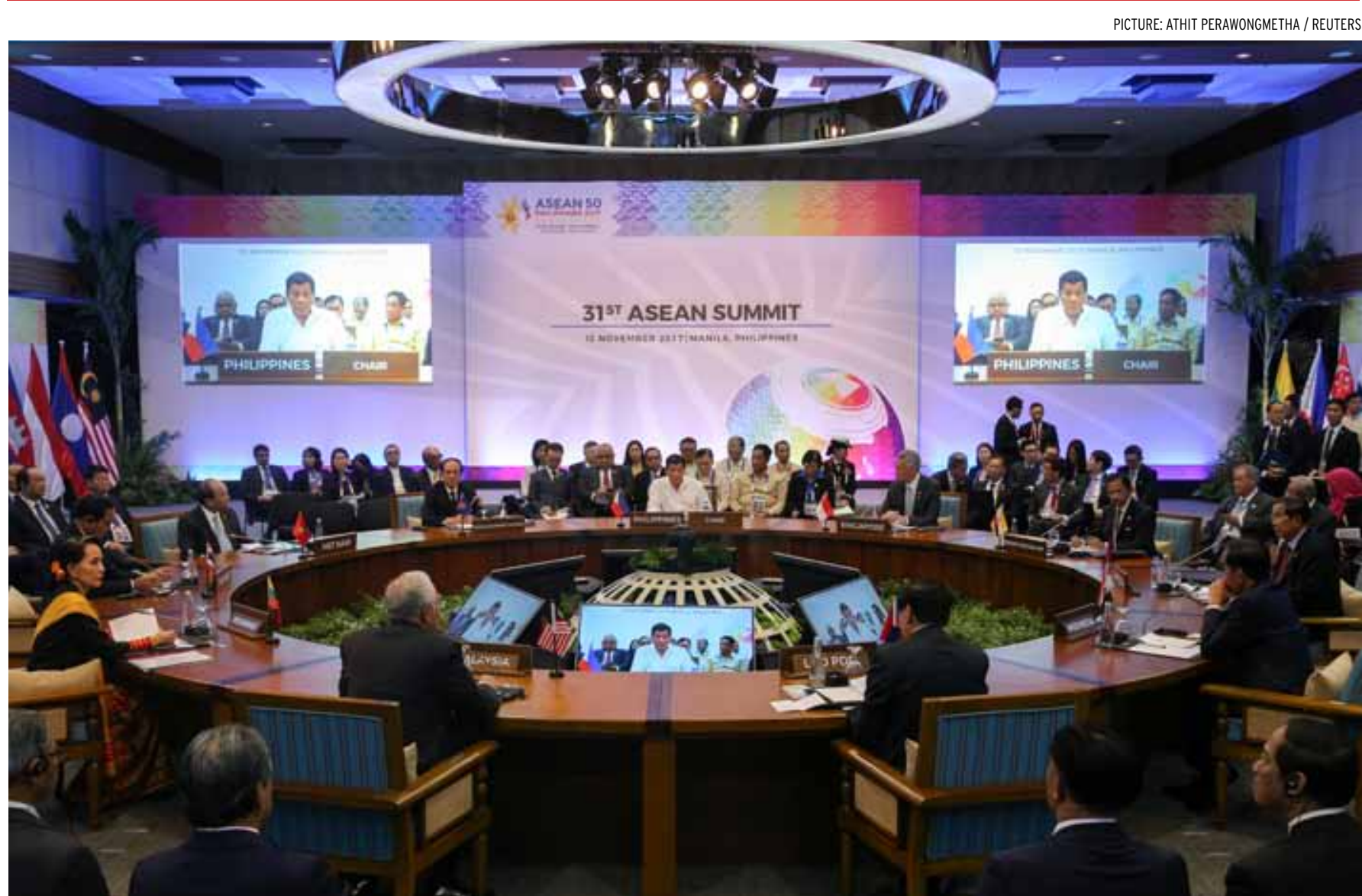

Leaders at the opening session of the 31st ASEAN Summit in Manila, the Philippines, on 13 November 2017.

\section{Pursuing growth: ASEAN against global trade trends}

\section{CHATIB BASRI}

$\mathbf{T}$ HE success story of the East Asian economy was about the conection between trade and industrialisation-look at the cases of Japan, South Korea, China, Taiwan and Singapore. Trade-oriented industrialisation drove regional economic integration in through trade and investment-and integration into the world economy that was made possible by conducive global economic growth and a relatively open global economy.
Unfortunately, the party is now over. Many economists are beginning to talk of a 'new normal' global economy with slower growth and trade. Brexit, the ascendency of US President Donald Trump and antiimmigration sentiment all point to a growing resistance to globalisation. At the March 2017 G20 meeting in Germany, even finance ministers and central bank governors backed away from agreement on support for free trade and investment.

It's premature to conclude that the world has fully embraced protectionism, but the conditions for trade liberalisation and negotiating trade agreements are tougher than they were. Economic recovery in the United States and some parts of Europe remains fragile, and China's growth though robust is also on the wane. Against this 'new normal' backdrop, what can ASEAN countries do to counter this trend and mitigate its impact? What role can regional cooperation play in addressing these emerging challenges in the global trade and investment environment?

Slowing economic growth will 
impact on job creation, and ASEAN nations cannot afford slow economic growth-more jobs are essential to win the fight on reducing poverty.

ASEAN and East Asia must continue to encourage economic growth to improve the socio-economic welfare of their citizens. Even though global growth is sluggish, East Asian economies still have relatively high growth. The potential is there. East Asia must strive to achieve it growth potential.

Fiscal expansion is one possible solution for those countries that have the fiscal space-though that's a luxury afforded to few countries in ASEAN. Room for monetary expansion is also limited due to the growing possibility of the normalisation of US monetary policy.

Forcing the pace on continued structural reform is where progress is vital. But structural reform is much easier said than done. Further unilateral liberalisation is not easy when the rest of the world is consumed by creeping protectionism, and the progress of a multilateral agenda is still in limbo as the WTO's Doha Round seemingly goes nowhere.

A more feasible way forward is a combination of structural reform and the revitalisation of regional cooperation.

Pursuing openness through regional economic integration will

\section{EASTASIAFORUM Quarterly}

IN OUR NEXT ISSUE ...

\section{Why ASEAN matters}

\section{Even though global}

growth is sluggish, East

Asian economies still have

relatively high growth.

\section{The potential is there}

not be easy. The trend towards deglobalisation demonstrates that the original model of globalisationrapidly reducing the barriers to trade of goods and services-does not have strong political backing. It's clear that economic reform and trade liberalisation need now to be accompanied by policies that ensure that 'losers' in realising the overall gains from trade are effectively compensated. Where distribution of the gains from trade has not been attended to, globalisation's positive impact has found less support among the people and political will for it has waned. A consequence is the pockets of deep political resistance to globalisation.

Restoring trust in globalisation is now a primary goal. This can be done by highlighting globalisation's success stories and its direct and positive impact on people's lives. The success of reform does not hang on the merits of the reform's agenda, but rather on political support-an intrinsic dilemma of reform is that the cost is more immediate and concentrated and the benefit is more diffuse and long term. This makes it necessary to get 'quick wins' or success stories to ensure political support.

These circumstances underline the need for multi-stage regional cooperation. This can start slowly and then tackle more complex issues. For example, instead of negotiating over how to lower trade barriers, negotiations can start on issues related to connectivity and capacity building.

These objectives are acceptable politically by nearly all member countries and can be economically beneficial. Revitalising the ASEAN infrastructure fund is another example of a 'low-hanging fruit' in regional cooperation.

If this kind of cooperation can be carried out, people will feel the real impact of regional cooperation and ASEAN states can move forward with a more complex agenda for economic integration.

The Regional Comprehensive Economic Partnership (RCEP) fits the bill and can now be brought into play. The Trans-Pacific Partnership is practically dead in the water since the United States withdrew. RCEP is the only way forward. RCEP provides an ongoing framework through which to promote open regionalism and an open international economy. RCEP is important for ASEAN as an initiative that was put forward when Indonesia was the chair of ASEAN in 2011-it is not a Chinese initiative, as some wrongly believe.

As the global economy and the support for globalisation both languish, ASEAN nations need to act immediately to preserve the economic order that gave East Asia such prodigious development. RCEP offers a practical way forward in global trade diplomacy-and ASEAN would be remiss not to pursue it fully at a time when it's important to our global economic future. EAFQ

\section{Chatib Basri is a Senior Lecturer at the Department of Economics, University of Indonesia, and formerly Indonesia's minister of finance.}




\section{Campus connections matter}

\section{BRIAN P. SCHMIDT}

C HINA is a partner of Australia and it must remain so. The two countries are geographically close, and the China-Australia Free Trade Agreement signed in 2015 has narrowed the distance further.

On 18 October, at the 19th National Congress of the Communist Party of China, the Chinese government mapped out its economic plan for the next five years and beyond. Extraordinary investment figures of around US $\$ 300$ billion are being reported for innovation and high-tech industries.

There are clear opportunities here for Australian research and development collaboration, and even greater opportunities for Chinese and Australian students in the future.

In international education, from schools to universities, the number of Chinese students studying in Australia rose this year to almost 170,000 , accounting for around 29 per cent of the total international student body.

There are significant benefits from international education in terms of Australian and Chinese students being able to build deeper engagement and collaboration. But, as recent news articles and academic debates reveal, there are also security concerns that may limit what we hold as the central idea of a great university education: academic freedom.

It is encouraging that Australia's relationship with China has become more mutual. The numbers of Australian students going to China has grown significantly, up 83 per cent since 2011. This helps to build

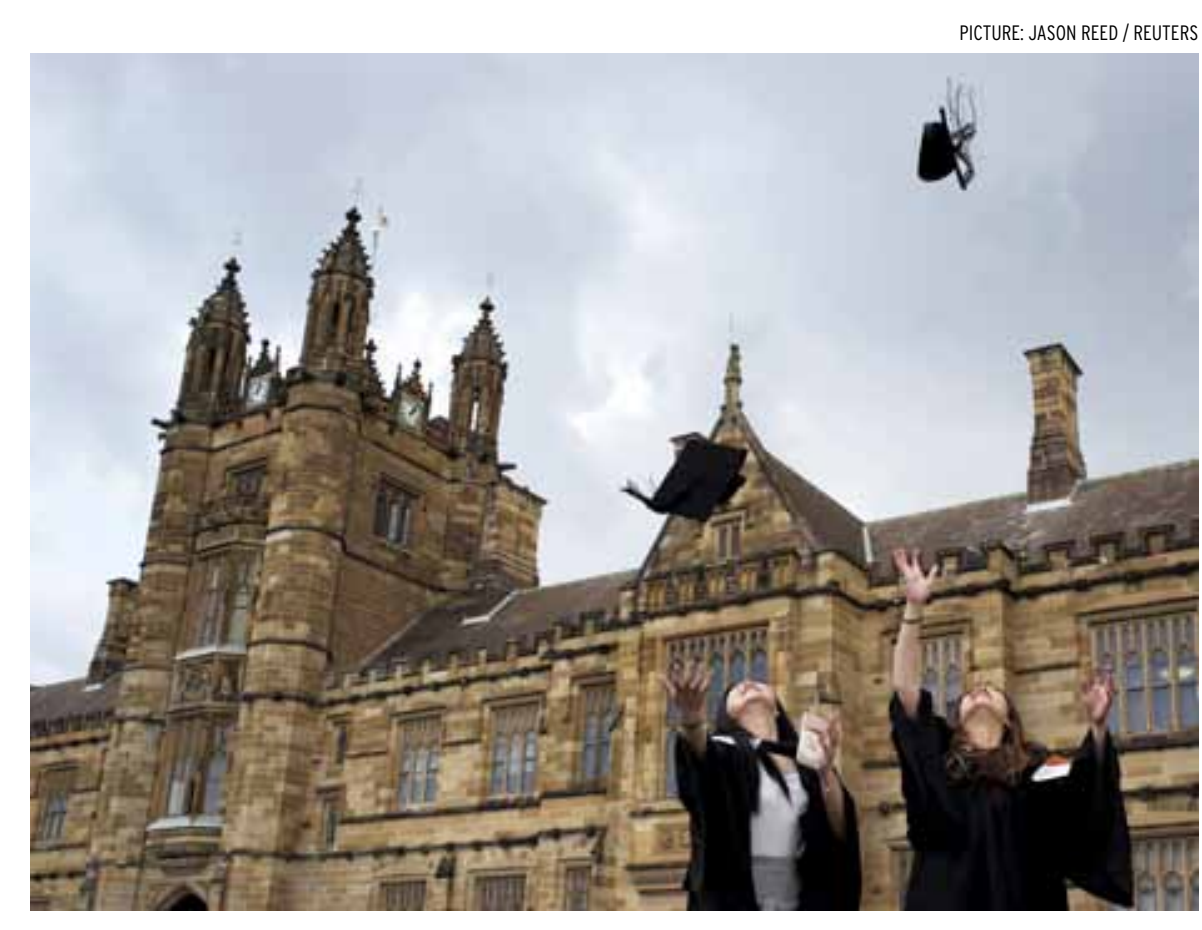

Graduates toss their mortar boards in the air after the conferring of degrees ceremony at the University of Sydney in April 2016.

Australia's knowledge of Asia, at the heart of which sits China. Nations can work better together when they understand each other's cultures and worldviews.

International engagement through education is not just good diplomatic practice. It is a major slice of the Australian economy, constituting Australia's largest non-mineral export. Education exports have earned Australia close to US\$28 billion this year.

Exporting education on this scale is an exceptional opportunity to build affinities across borders and cultures, and create a network of influence and soft power that will have reach in the decades to come that is difficult to imagine now.

If Chinese young people return to China having had a wonderful experience in Australia, this creates a network of alumni who are also ambassadors and champions for the nation. In this century, when China is so crucial to the world's economy, security and stability, this magnifies Australia's influence.

But international education is also complex, and at its heart involves people making significant sacrifices and huge adjustments to grab an opportunity.

Inevitably, many international students, including the large numbers in Australia right now, experience the difficulties of adjusting to a new society and study environment. Some of these are about acclimatising, overcoming the language barrier and getting familiar with the culture.

Others are more serious but much less common. If you follow the media 
commentary, you will have seen allegations of spying, monitoring by the embassy and other students, infiltration of Australian society, or harassment of families at home.

It is incumbent on Australian universities to recognise these challenges and work in partnership with government to address them.

Whatever measures we take, at the heart of our response will always be a commitment to academic freedom, and making sure our students are exposed to new ways of thinking. These philosophies are embedded in our policies and are an essential part of the fabric of who we are.

The core of our academic success is the following key principles-that everyone is free to challenge ideas, to counter received wisdom, and develops the ability to feel comfortable being challenged.

The goal is for graduates of Australian universities to be resilient, respectful, critical thinkers. That is the set of skills that Chinese and other foreign students in our system are paying to learn.

But part of acquiring intellectual maturity is rooted in belonging. And that requires a campus community that is welcoming and cohesive.

There is sometimes a tendency for students from different backgrounds to club together based on their common nationality. This is understandablebut if that dominated the overseas student experience on our campuses, it would not be optimal.

How can universities encourage a more cohesive university community? By creating structures and mechanisms for international students that make it easier to engage, and provide alternatives to self-organised or government-organised activities, although these activities will be naturally a part of the mix.
Part of acquiring

\section{intellectual maturity is}

rooted in belonging. And

that requires a campus

\section{community that is}

\section{welcoming and cohesive}

Simple changes in residential halls to prioritise housing a wider range of nationalities enables people from across the world to live together, engaging naturally and experiencing each other's cultures.

What makes student communities so richly diverse and fulfilling is that they are made up of individuals. And this is the key insight in how Australia engages with students from China, or any other country: that it does so through individuals, each of them unique.

Each one of the Chinese students in Australia is an individual. Not all are from the People's Republic.

Of course, security concerns need to be acknowledged and addressed. This is part of ensuring that our international relationships-whether in research, teaching or student recruitment-are sustainable and in the national interest.

But security issues also need to be put in careful context. There is no upside to letting security concerns about a small proportion of international students affect attitudes to the wider international student body, whether from China or anywhere else.

What Australians absolutely must avoid is the flat-out wrong idea that
Chinese students are all spies, or incapable of critical enquiry, or that they all think alike.

Students who enter The Australian National University, for example, meet its tough entry thresholds and pass our rigorous assessments, and are some of the very best and brightest. They are so impressive, so extraordinarily bright and open to new ideas, that they are able to succeed in the highly competitive environment of a topranked international university.

And, let's not forget, they do all of this in a language that is usually not their first, while coping with an unfamiliar culture, a long way from the support that they would have at home.

Given the contribution they make, and their potential role as champions and ambassadors for Australia in the years ahead, to allow negative perceptions of Chinese students to set in would be doing Australia a huge disservice.

There is a fork in the road for Australia and China-one direction where the two countries work cooperatively, and one where they do not. The first way is one of mutual prosperity. The second is full of risk.

Working cooperatively does not mean giving up on the diligence surrounding Australia's national security, but it does mean creating a more connected, dynamic and ultimately, peaceful world, which is in Australia's and everyone's interests. EAFQ

Brian P. Schmidt is Vice-Chancellor and President of The Australian National University, and the recipient of the 2011 Nobel Prize in Physics. This article is an edited and abridged version of the Keynote Address at the Welcoming Dinner of the Sixth National Meeting of China Matters in Canberra on 16 October 2017. 


\section{China's grand strategy in a new era}

\section{ZHONG FEITENG}

N THE 19th Chinese Communist

Party (CCP) Congress Report, President Xi Jinping claimed that China was entering a 'new era. China has transformed its newfound riches into strength. In the next 30 years, China will inexorably become a leading global power. The big question for the world is what will be the implications of China's new power?

The successful story of China's past four decades is a predictor of the future. Xi's vision for China is a 'twostage development plan'. In the first stage, from 2020 to 2035, the primary goal is to build on the foundations of China's modern economy. In the second stage, from 2035 to 2050 , China will seek to become a state with substantial global influence.

It is not the first time the CCP has laid out a grand plan like this one. Deng Xiaoping-a central figure among the second generation of Chinese leaders-set out a 'three-stage development plan' in 1987.

In Deng's vision, China's strategic objective was to become a mid-level developed country by 2050 . The first stage was to double GDP and GDP per capita by the late 1980 s. The second stage was again to double GDP and GDP per capita by the end of the 20th century. The third stage would only be achieved in another 50 years. Xi's 'two-stage' plan is just the third stage of Deng's longer-term vision. In this sense, the continuity of China's grand strategy is clear.

Deng's vision was quickly written

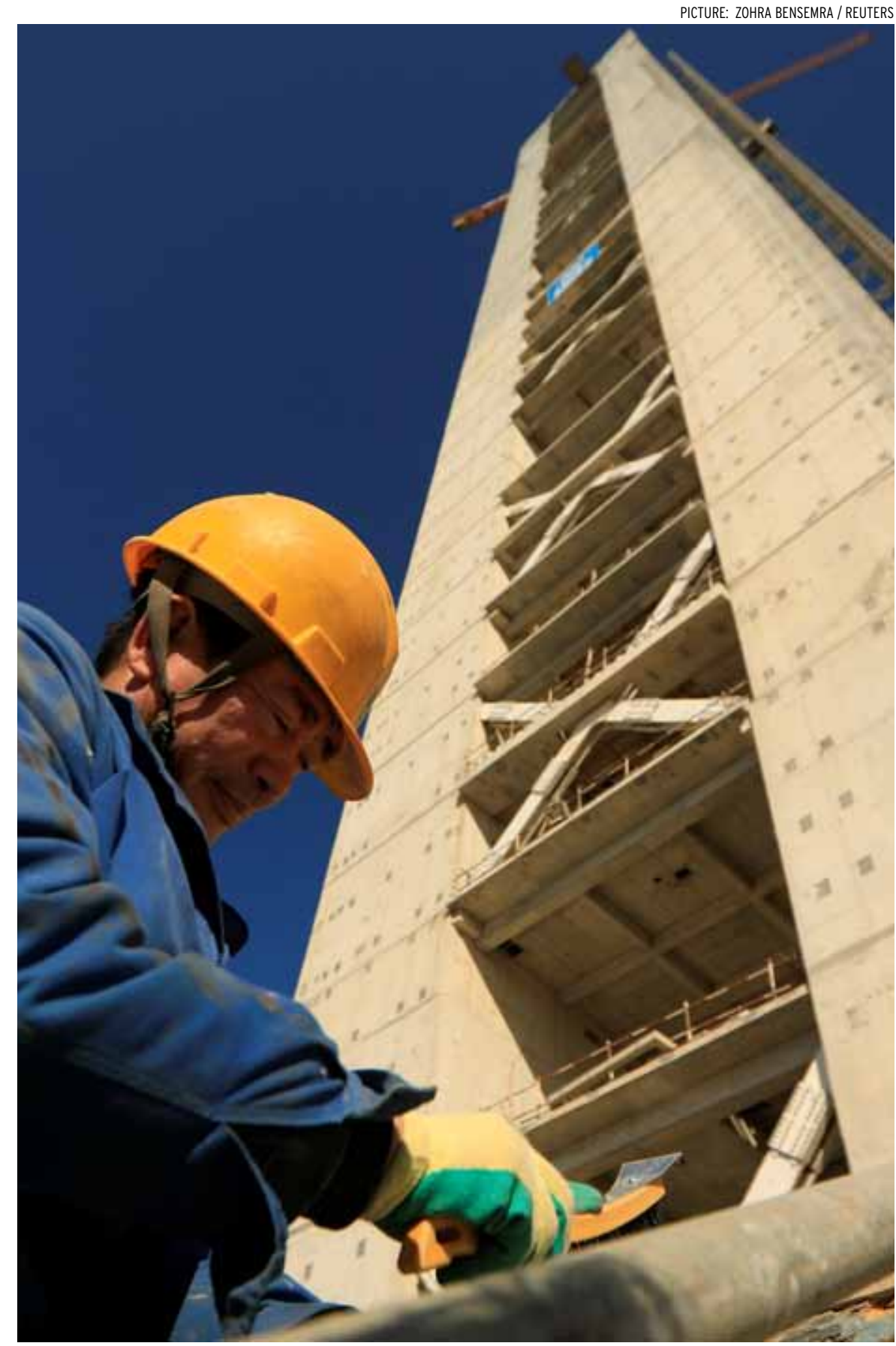

A Chinese worker on the construction site of the 270-metre-high minaret of the new Great Mosque of Algiers, which is being built by the China State Construction Engineering Corporation. China is trying to translate its home-grown development knowledge into international development. 
into the 13th CCP Congress Report and became the guiding principle for China's economic reform and openingup policy. In line with that vision, China achieved astonishing economic growth. According to International Monetary Fund's (IMF) World Economic Outlook, China's annual growth rate averaged 5 per cent from 1960-77 and grew at 10 per cent from 1978 to 2011.

Such growth figures are remarkable. Even Japan did not grow at 10 per cent a year for more than 30 years. As a result of 30 years' of rapid growth, China escaped the poverty trap in 1998 and became an upper-middle income level country in 2010. According to IMF estimates, China's GDP grew from US\$305 billion in 1980 to US\$11 trillion in 2017.

Deng and other Chinese leaders have always emphasised that rapid growth could not be achieved without a stable and peaceful regional and international environment. To realise economic reform and open up, China's foreign policy experienced a paradigm shift from alliance, revolution and conflict, to an independent, peaceful and cooperative one in the early 1980 s. Further, China's grand strategy is seeking for a balance between internal and external factors, and is focused on development rather than power.

This logic is dramatically different from that of the Mao era and also departs from conventional international relations theory. For example, hegemonic stability theory argues that an open world economy needs a single great power. Regional or international order is only created by a great power or great-power struggle. But China was not considered a great power by most international relations theorists by any criterion till the 1990s.

China has practised multilateralism with ASEAN countries since the early
1990s.It has also gradually established new types of partnerships with many other countries, including Russia and the major powers. In January 2017, the Chinese government released its White Paper on China's Policies on Asia-Pacific Security Cooperation, which proclaimed that 'the development of a regional security framework should be advanced in parallel with the development of regional economic framework'

In 2017, China's per capita GDP will come close to US\$8600. Although China's per capita GDP is still lower than the world average, and is only 14.4 per cent of that in the United States, China is no longer a poor country. China's economic turnaround is very important. It is one of the crucial elements that distinguishes Xi's grand strategy from Deng's vision. As Xi declared in his 19th CCP Congress Report, China 'has stood up, grown rich, and become strong', and the major task for the next generation is to 'embrace the brilliant prospects of rejuvenation ... It will be an era that sees China moving closer to centre stage and making great contributions to mankind.'

Achieving Deng's three-stage development is crucial for China's rise. Wealth is the prerequisite to safeguard sovereignty, security and development. But it is not easy for China to strike

A prosperous China

will not only contribute

material welfare but

also new ideas around

the world the right balance between wealth and power. Historically, China was a rich and powerful state. During the Song dynasty (960-1279), China was considered the richest state in human history. But with the rise of the Mongol empire, the global centre of wealth shifted to the Mediterranean, including Spain, Venice and other Italian city-states.

The rise and fall of the great powers in Western Europe brought modern ideas, rules and institutions to the rest of the world. The modern history of China since the mid-19th century is partly the consequence of global conquest by Western powers. But it took China a long time to learn from their successes and mistakes.

Based on new thinking about the relations between wealth and power, it is natural for China to seek security through development over the next 30 years or so. A prosperous China will not only contribute material welfare but also new ideas around the world.

Outward foreign direct investment, international trade and the movement of large numbers of tourists from China will provide resources and a boost to global markets. As more countries benefit from Chinese-style modernisation, ideas will change about China's rise.

China is trying to translate its own local development knowledge into international development and is learning to provide public goods around the world through the Belt and Road Initiative. Other countries will derive mutual benefit from China's ambitious plans, and that will contribute to China's new goal of common development. EAFQ

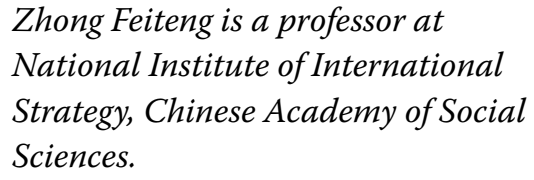

Zhong Feiteng is a professor at National Institute of International Strategy, Chinese Academy of Social Sciences. 


\section{Chinese-language media and social cohesion in Australia}

\section{WANNING SUN}

C VEN though Chinese-language media have been around from the first Chinese migration to Australia in the nineteenth century, mainstream society's understanding of the nature and function of this sector is at best partial and simplistic, at worst misinformed and erroneous.

For many years, these media, like other ethnic community media in Australia, were considered to be of relevance only to the Chinese community and of little interest to the English-speaking mainstream. Amid mounting interest in the Chinese media in recent months, a few journalists have used the phrase 'black box' to describe the challenge they face in understanding the implications of Chinese-language media for Australian politics, society and culture. This is partly due to the language barrier: most mainstream Australian commentators who espouse strong views on these media do not read or understand Chinese, and have to take the views of other commentators at face value.

In response to mounting interest in the Chinese media since China's rise, and a narrative of China's growing influence in Australia, I was commissioned to write a major report on Chinese-language media in Australia. The report paints a perplexing and complex picture of the fast-changing landscape of the sector.

Most media and public commentators picked up on one message from the report-namely,

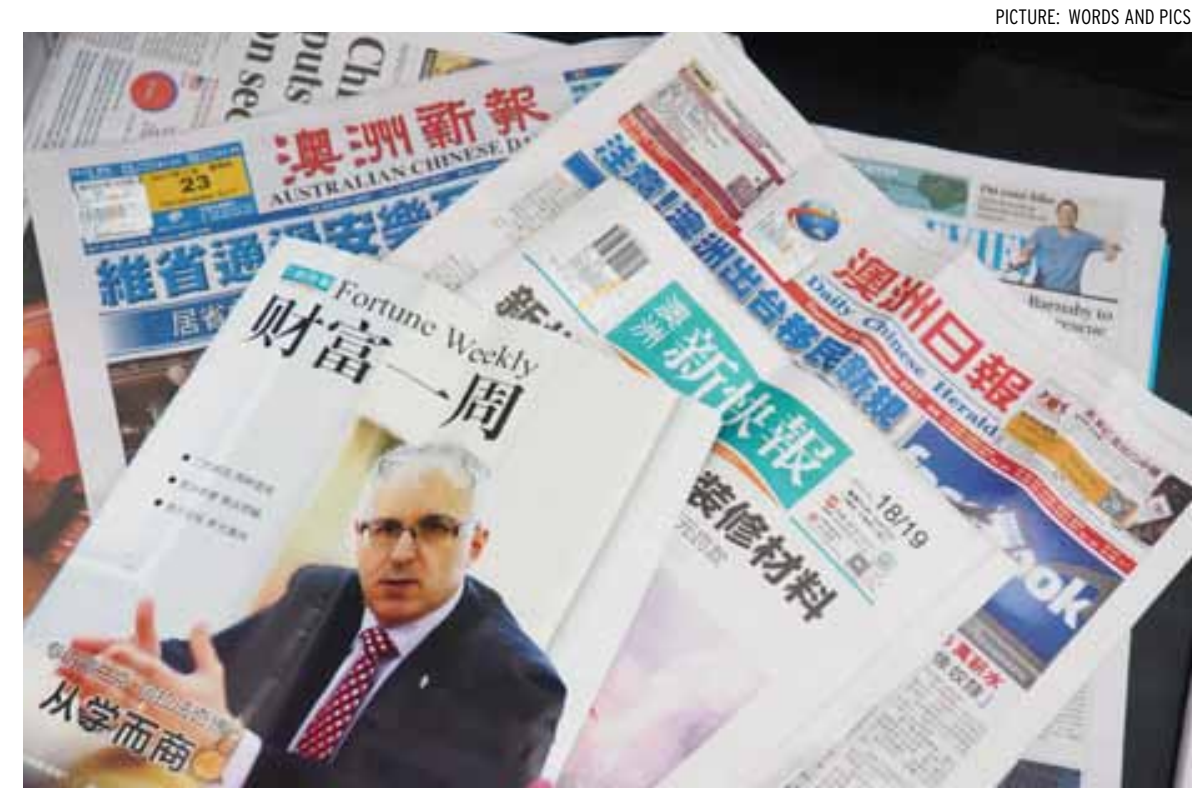

that China's state media have made significant inroads into Australia's ethnic Chinese media, and that, in contrast to the mostly anti-communist stance of a few decades ago, the majority of these media report on China favourably.

What was less heeded was a revelation which, to me, was as important as this change, if not more so: the emergence of new online Chinese-language news media, whose popularity and impact is exponential thanks to the ubiquity of WeChat-the most popular Chinese social media platform both within the People's Republic of China (PRC) and globally. The emergence of this digital and social media sector, which in Australia caters mostly to youngergeneration migrants and international students from the PRC, has seen the relationship between China's state media and Australia's Chineselanguage media become blurred and more ambiguous.

Nationalistic or patriotic pro-China sentiments erupt from time to time in the new media, especially when China and Australia are at odds over certain issues. But what are the sources of these sentiments? Equating them with Chinese government propaganda and a deliberate and orchestrated outreach to Chinese migrants and students is not borne out in extensive and engaged ethnographic research.

The reality is that pro-China patriotism in the diaspora is a child with many foster parents, none of whom can claim sole credit for its growth. The official state ideology indeed promotes loyalty to China and, by implication, to the political party that rules China. But equating nationalism among members of the diaspora with Chinese government activity gives indoctrination efforts more credit than they deserve, while denying Chinese individuals the 
agency and capacity to make up their own minds.

A more powerful and insidious source of nationalism is the marketsomething that mainstream Australian commentators persistently overlook. Patriotism is big business. It helps sell everything from hard liquor (think Wuliangye: 'China's spirit, global taste') to air conditioning (think Gree: 'Made in China, Loved by the World').

Market patriotism, a global not merely Chinese phenomenon, also helps explain the modus operandi of many cultural productions. Mainstream commentators often quote China's Global Times as the Chinese nation's official mouthpiece, but the nationalistic, sometimes jingoistic, tone in its reporting on China's foreign policy is more driven by the mandate to sell copy and increase circulation than by a need to toe the Party line.

Patriotism has also become the most profitable emotion to ensure cinematic box office success. Wolf Warrior II (zhan lang II), centring on the story of China's successful and epic-scale evacuation of Chinese nationals from world trouble-spots, mixes all the classic Hollywood ingredients-action, spectacle, adrenaline and a healthy dose of pride in one's own country. Released in July 2017, Wolf Warrior II broke numerous box office records and became China's highest-grossing film ever. Its main goal was to capitalise on nationalismthe only game in town.

Patriotism also takes on new forms in the age of the internet and social media. Strong emotions, words and reactions, such as love of one's country and hatred for a national enemy, can spread like a virus. Since more clicks mean more chance of monetisation, capitalising on patriotism is both politically safe and financially lucrative for bloggers, micro-bloggers and video streamers. Patriots are often little more than internet-based fans peddling the sentiments of other people-especially celebrities-without too much original thought of their own. In Chinese, they are derogatively referred to as 'meloneating mobs' (chi gua qunzhong).

A sub-category of the internetbased social identity that has contributed to promoting pro-China patriotism is the 'little pinko' (xiao fenhong). These tend to be young people, many of whom are living or studying outside China, who have direct or personal experience of living as a minority in the West. While on a daily basis these individuals are by nature non-political, they are shown to have a tendency to 'rise to the occasion' when China is demonised or wrongly criticised.

The Yang Shuping incident, where a Chinese student at Maryland University became the person every Chinese netizen loved to hate for criticising her motherland and singing the praises of America, testifies to the power of little pinkos.

Since the rise of China, and especially since the 2008 Beijing Olympics, little pinkos have become watchful of things being said or done that may 'hurt Chinese feelings'. Their responses are usually visceral, and

The Australian media's

own problematic coverage

of many China-related

issues is . . another spur

to Chinese patriotism even though they may use official rhetoric in promoting a love of China, do not imagine that they are creatures of the government.

Australia's digital Chinese-language media became the main platform for the war of words between Chinese swimmer Sun Yang and Australian champion Matt Horton during the Rio Olympic Games, and again when the Australian swimming team's website was hacked-another example of the digitally savvy little pinkos in action.

The source of this nationalistic sentiment is complex, and the Australian media's own problematic coverage of many China-related issues is increasingly another spur to Chinese patriotism.

If mainstream Australian commentators continue to talk about Chinese patriotism, the AustraliaChina relationship and Chinese migrant community media in ways that are one-dimensional, and if they continue to portray the Chinese community and its media in Australia as the brainwashed stooges of the Chinese government, they may well end up alienating this community and harming social cohesion in multicultural Australia, not to mention jeopardising Australia's productive economic relations with China.

This message has mostly gone unheeded. And sadly, the failure to heed the message is bearing undesirable fruit: the sense of alienation in the Chinese-speaking community, including both PRC migrants and Chinese migrants of other origins, is palpable and widespread. The damage is being done, and the process continues. EAFQ

Wanning Sun is Professor of Media and Communication Studies in the Faculty of Arts and Social Science, University of Technology Sydney. 


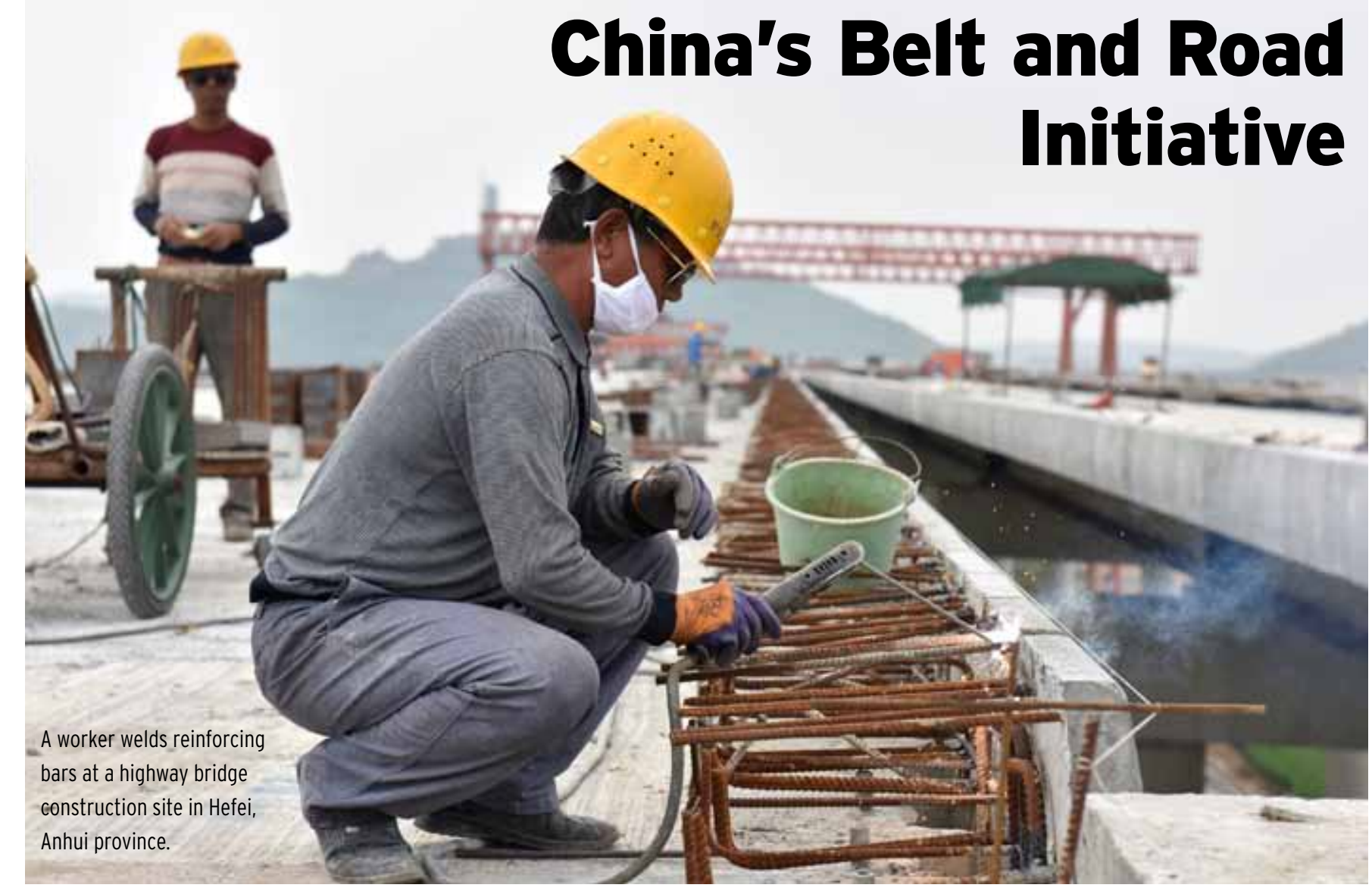

EVELYN GOH AND JAMES REILLY

\section{A} S THE dust settles from the Chinese Communist Party's 19th Congress, one of the strongest edifices left standing is Xi Jinping's signature foreign policy initiative-the US\$1 trillion Belt and Road Initiative (BRI). Two members of the BRI Leading Small Group, Wang Hunning and Wang Yang, secured five-year positions on the reshuffled Politburo Standing Committee. The BRI even received an awkward mention in the revised Party Constitution. With Xi Jinping's leadership looking more impregnable than ever, the BRI is poised to shape China's economic engagement with its Asian neighbours for years to come.

While experts widely agree that one of Xi's core goals for the BRI is to bolster Beijing's regional influence, few have asked how building infrastructure might generate political influence.

One type of political influence is 'connectivity power'-the influence a central government accrues through infrastructure projects that connect its domestic periphery and neighbouring states to the central core economy. Connectivity power is evident when one alters 'an actor's preferences and behaviour in favour of one's own aims.' This influence may be indirect, unintentional and structural, so how can it be observed, measured and compared?

Three types of infrastructure projects are most likely to generate connectivity power: transportation (roads, railways and ports), communication (cellular networks, internet cables) and energy (oil and gas pipelines, hydropower dams, electrical lines and grids).

Within these projects, China's connectivity power is likely to emerge through four mechanisms. First, and most directly, new infrastructure projects should bolster the flow of people, goods, capital and energy. Since the BRI is essentially a promise for a US $\$ 1$ trillion state-backed investment surge, capital flows are in particular likely to yield an 'early harvest'.

Indeed, the BRI already appears to be stimulating additional investment, as more Chinese investors take a stake in firms in BRI recipient countries, perhaps in the expectation that they will receive easier access to BRIearmarked capital or can capitalise upon Beijing's efforts to boost exports 
from BRI-recipient countries. By August 2017, the value of Chinese mergers and acquisitions in the 68 countries officially participating in the BRI already totalled US\$33 billion, surpassing the US\$31 billion tally for all of 2016.

Trade patterns are less likely to change dramatically, since China already represents the most important source of imports for about three quarters of BRI countries and is the most important trading partner for just under half of them. Yet even in trade the BRI's impact is emerging. China's trade with BRI countries in the first half of 2017 rose 4 per cent faster than China's overall foreign trade. Standouts include Russia, Pakistan, Poland and Kazakhstan-all key players along the new Silk Road.

As new energy projects come on line, they will also begin to reshape energy flows. For instance, the Kyaukphyu-Kunming natural gas and oil pipelines across Myanmar and into Yunnan province enable Beijing both to diversify its energy sources and tighten economic interdependence with Naypyidaw.

S ECOND, connectivity projects help put China at the centre of a thickening web of linkages, bolstering Beijing's capacity to set the standards by which transborder networks operate. China's high-speed trains and ultra-high voltage electrical lines, for instance, will likely shape regional standards as they begin to stretch beyond China's borders.

In China's bid for global influence, currency may well be the most significant standard it can aim to reset. Chinese currency (RMB) internationalisation is meeting Xi's call for more 'early harvests' from the BRI. Over half of the 35 economies that have signed currency deals with China are in the BRI. Of the 68 BRI countries, one third now have direct access to RMB from their own banks.

Economists confirm that easy access to $\mathrm{RMB}$ promotes trade with China. Mongolia is a prime example. Almost 90 per cent of its exports go to and one third of its imports come from China. In 2014, Ulaanbaatar signed an RMB15 billion (US $\$ 2.2$ billion) currency swap agreement with China, which was extended for another three years in July 2017.

Connectivity power can also extend into institutions. Established multilateral development institutions, such as the Asian Development Bank, may incorporate Chinese backed projects. For instance, the World Bank funded the Kazakhstan stretch of the Western Europe-Western China Highway, which will now serve as the main roadway of the BRI's central corridor.

But such synergy can cut both ways - the involvement of western financial institutions might dilute Beijing's influence over the terms of lending, or they may help legitimise and amplify China's model of infrastructure-led development. The funding surge behind BRI can also bolster the standing of China's own financial institutions, particularly the China Development Bank and Silk Road Fund, as well as the Beijing-backed Asian Infrastructure Investment Bank and the New Development Bank.

A fourth pathway of potential influence runs through the domestic politics of recipient countries. Beijing hopes that domestic groups benefitting from the infrastructure projects will lobby on China's behalf. Greece's influential shipping industry, for instance, has quietly nudged Athens toward a non-confrontational China policy following massive Chinese investment into Greece's shipping sector.

Like any ambitious policy initiative, $\mathrm{Xi}$ Jinping's BRI strategy entails considerable risk. Beijing-backed infrastructure projects can alienate influential groups and trigger populist backlash, pushing leaders to adopt anti-Chinese rhetoric, as Mongolian President Khaltmaa Battulga did during his July 2017 election.

F URTHER, while extending massive loans may initially bolster Beijing's influence, leverage shifts to the host country once the project is underway, as was starkly evident in the case of the Myitsone Dam in Myanmar. Since the Myanmar leadership bowed to public pressure and froze the massive project in 2011, Chinese investors and officials have been unable to compel a policy reversal or even secure compensation, leaving the project's future unresolved.

Increased connectivity also facilitates factors of instability. Guns and drugs are smuggled into China through burgeoning trade routes. Beijing has long been wary of engagement between its Muslimdominated provinces-Xinjiang and Ningxia-and the Muslim world in Central Asia and the Middle East due to fears of importing instability.

As Deng Xiaoping warned decades ago, 'when you open the window, a few flies will come in. Yet like Deng, Xi Jinping appears eager to take this risk.

Evelyn Goh is the Shedden Professor of Strategic Policy Studies at the Strategic and Defence Studies Centre, The Australian National University.

James Reilly is an Associate Professor at the Department of Government and International Relations at the University of Sydney. 


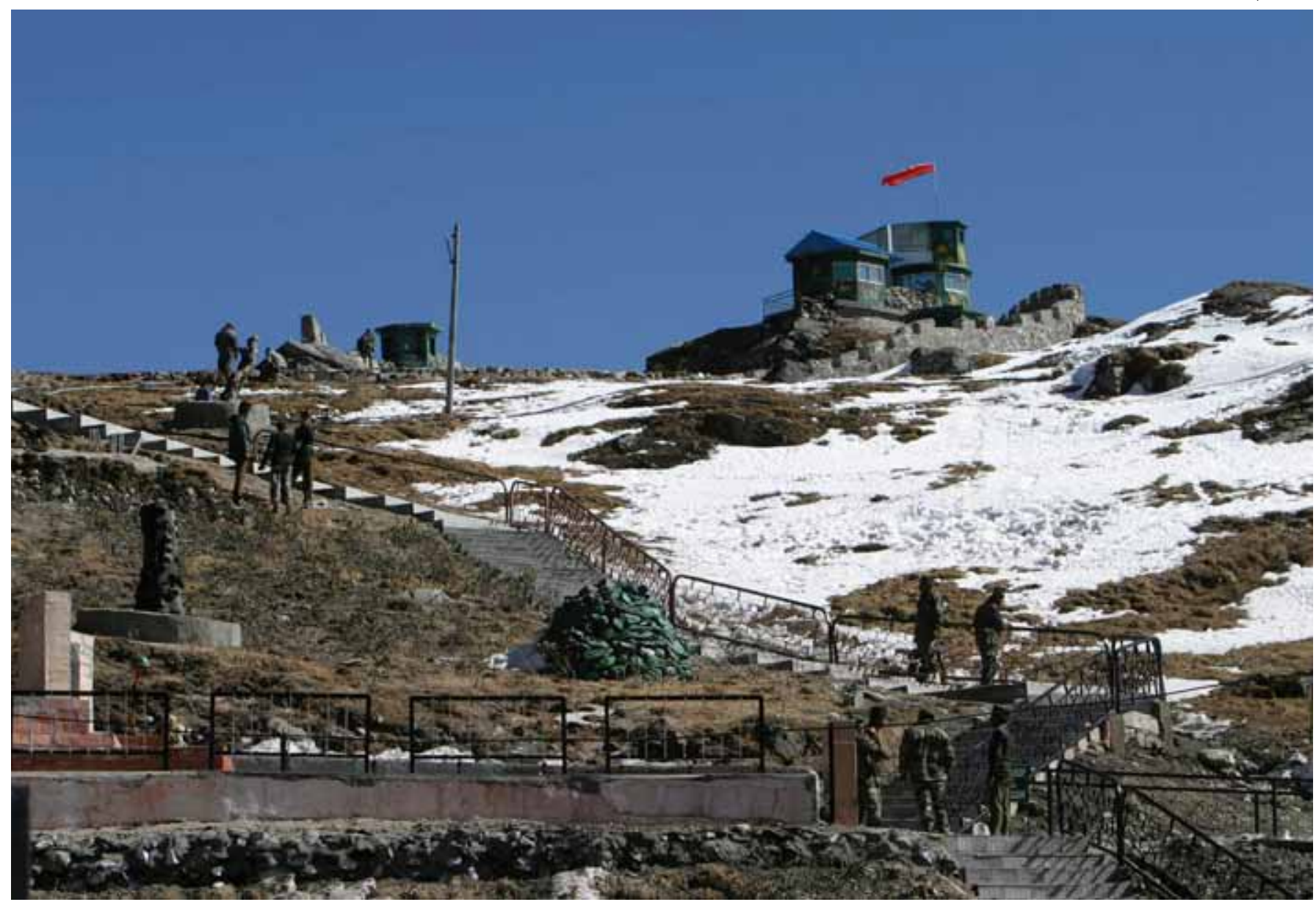

Indian soldiers at the India-China trade route at Nathu-La, 55 kilometres north of Gangtok, Sikkim. The nations share a 4000-kilometre-Iong border.

\section{How will India contend with China's growing power?}

\section{CHITRAPU UDAY BHASKAR}

C HINA and India have a complex and prickly relationship, a consequence of geography, history and recent experience between two uneasy modernising nation-states. An unresolved territorial and border dispute led to a brief war between the two countries in October 1962 and the humiliation of India in that confrontation remains part of its collective national memory. This reality shapes India's response to China's increasing influence and power in the region today.

When it comes to assessing national power, the differing trajectories of Chinese and Indian GDP since 1960 and the current disparity between them is quite stark. In 1960, China's GDP was half that of India. Despite its internal wobbles, in 2017 China's nominal GDP is estimated to be US\$11.8 trillion, while India's is closer to US\$2.45 trillion. China has successfully 'risen' and now has the world's second largest GDP. Some expect it to displace the United States as number one within a decade.

Increases in national military power are commonly linked to a country's overall national expenditure-so the wealthier a nation, the more it can allocate to security. In 2015 China allocated US\$141 billion to defence and increased this to US $\$ 215$ billion in 2016. In contrast, India allocated US\$55.9 billion in 2016. 
For China, India remains the intangible challenge in Asia-a comparable nation-state whose diversity and democratic ethos are in contrast to the authoritarian one-party neo-communist state. India's efforts at enabling the birth of Bangladesh in December 1971 stoked a deep anxiety in China. Beijing came to the conclusion that India had to be contained within the subcontinent and kept in a state of extended disequilibrium.

This geopolitical template provides the context for the strategic partnership that China has maintained with Pakistan since the early 1970s. This may have been a factor in China's repeated blocking-most recently in October 2017-of the US-led UN Security Council vote to blacklist Pakistan-based terror group Jaish-eMohammad's chief, Masood Azhar.

Beijing has used its comprehensive economic and military capability to enhance its footprint in India's neighbourhood, including in Bangladesh, Sri Lanka, Nepal, Myanmar and most recently the Maldives. Most of these states have become heavily dependent on China rather than India for their economic and military needs, partly because of the difference in the two countries' military and economic power.

$$
\text { B }
$$
ANGLADESH illustrates how growing Chinese power has shrunk India's profile. Over the past decade China has displaced India as Bangladesh's largest trading partner-in 2015, imports from China (including Hong Kong) were 27 per cent of Bangladesh's total imports, while India held closer to 12 per cent.

The Bangladeshi military is also importing materiel from China, including submarines. This means that two of India's closest neighboursPakistan and Bangladesh-are becoming more dependent on Beijing, compounding India's security dilemma.

But an unresolved territorial border that extends over 4000 kilometres and that led to the standoff between India and China on the Doklam plateau from June to August 2017, as well as China's strengthening military relationships in the shared region, are only part of India's security challenge.

China's investment in the Belt and Road Initiative (BRI) aims to help it to overcome the 'Malacca dilemma', whereby most of its energy supply needs have to pass through the Straits of Malacca. The Chinese investment in ports along the Indian Ocean littoral has often been described as a string of pearls and both Gwadar in Pakistan and the Chinese military station in Djibouti point to a near-permanent Chinese presence in the Indian Ocean. These placements allow China to protect or circumvent the Straits Malacca problem.

So how has this spread of Chinese power affected India? Unresolved border tensions and the recent Doklam crisis, when linked with President Xi Jinping's vision outlined at the 19th Party Congress, suggest that the probability of a similar standoff remains high. Beijing has also demonstrated its assertiveness in the maritime domain in Southeast Asia.

The Indian response to the spectrum of challenges presented by Chinese power is multipronged. Doklam is a reflection of the current

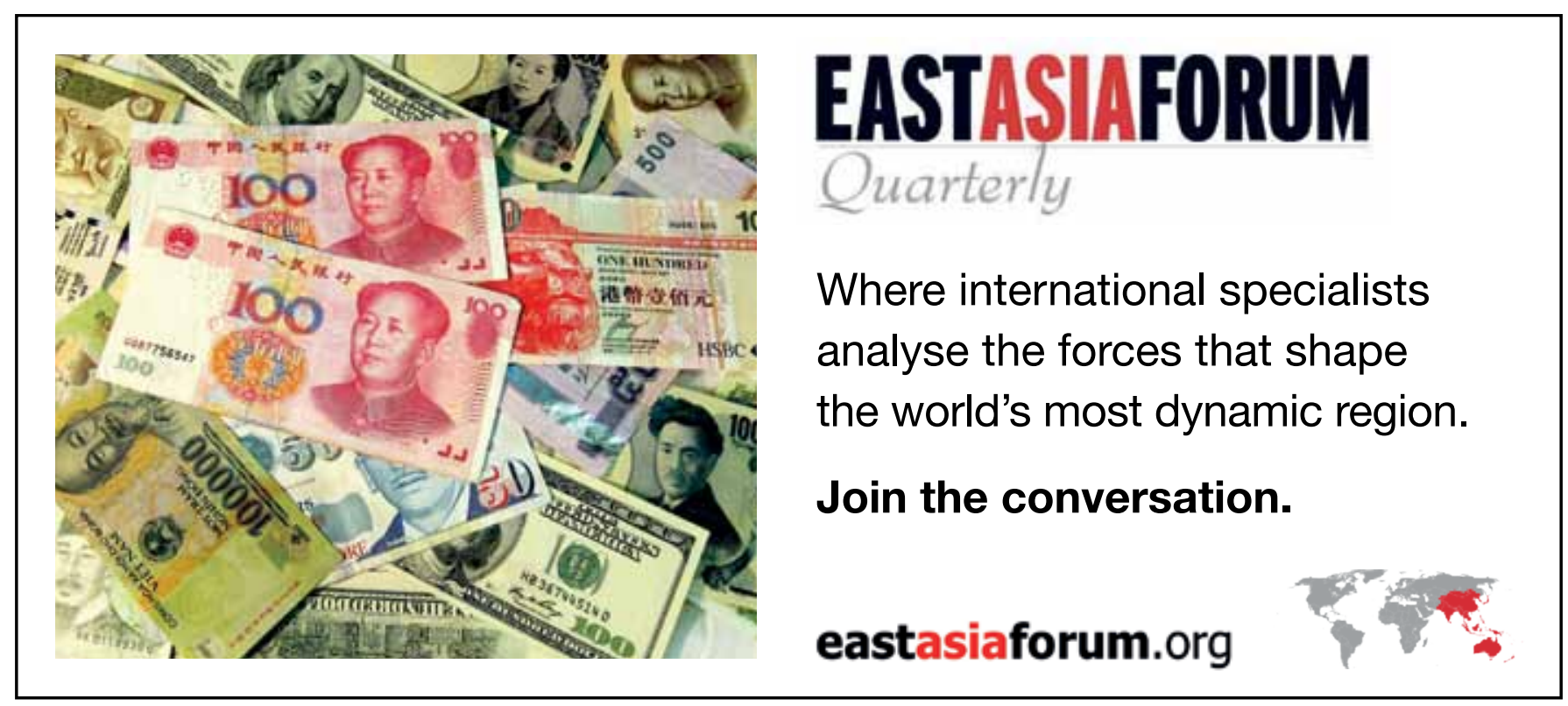

36 EAST ASIA FORUM QUARTERLY OCTOBER - DECEMBER 2017 


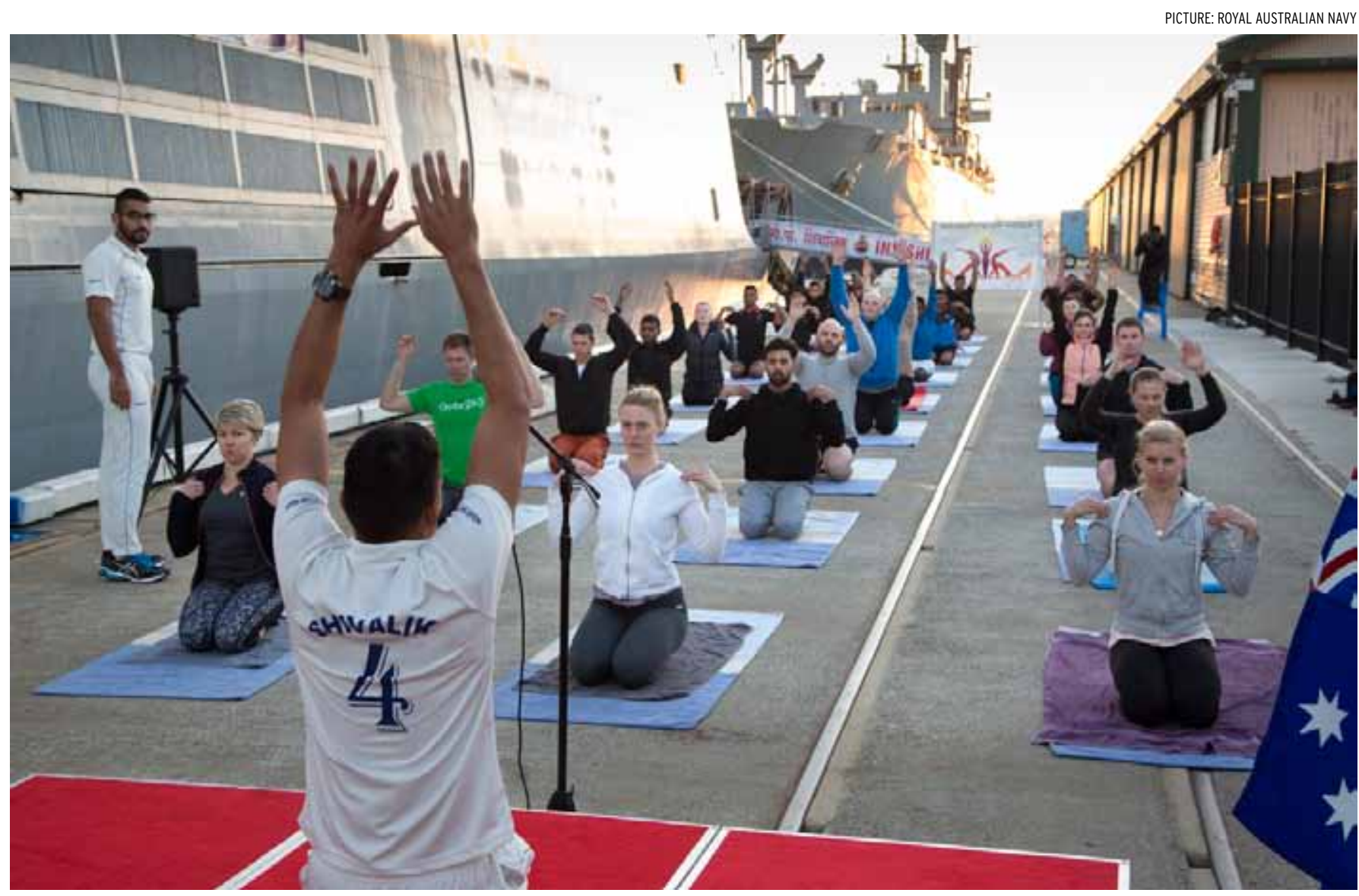

Fitness instructors from the visiting Indian Naval Ship (INS) Shivalik give yoga lessons to Australian personnel in Fremantle before the beginning of a joint fleet exercise in June 2017. Australia is seen by some commentators as a potential fourth partner in an India-Japan-US maritime arrangement.

Indian resolve to act unilaterally and remain firm, even if China adopts an intimidating posture. Will the results for India be the same? Perhaps notbut the raising of stakes by China will not be cost-free.

At the bilateral and multilateral levels, India's Modi government is exploring new partnerships that could become more robust and focused, particularly in the maritime domain. Good order at sea and freedom of navigation (FON) in the Indo-Pacific is now packaged as a collective security objective and China is being encouraged to come on board. India's bilateral partnerships with the United States and Japan have acquired a visible naval and maritime sheen and the possibility of this evolving into a quadrilateral relationship-with
Australia as a partner also-has been endorsed by President Trump on his recent trip to Asia, though it's still a work in progress.

If this four-way relationship acquires greater military and policy credibility, then a 'diamond necklace' could emerge-stoking the Malacca dilemma in an unambiguous way.

Much will depend on the domestic politics in the four democraciesIndia, Australia, Japan and the United States-and the degree to which their corporate and security elites harmonise their views about how to manage China.

But the exigency to constrain China by suasion will not unfold in a linear manner, nor is it set in stone. The US-China relationship is more opaque and deeply intertwined than it appears to be in the public perception. President Donald Trump's five-nation tour through Asia in November 2017 and its outcome will offer valuable cues about how Beijing under a more confident President $\mathrm{Xi}$ will use its power and the degree to which the Belt and Road Initiative can accommodate it.

Whether China becomes more revisionist or is willing to maintain something like the status quo in global affairs will have significant regional implications that will shape India's response in the longer term. EAFQ

Chitrapu Uday Bhaskar is a retired Indian Navy Commodore and Director of the Society for Policy Studies, New Delhi. 


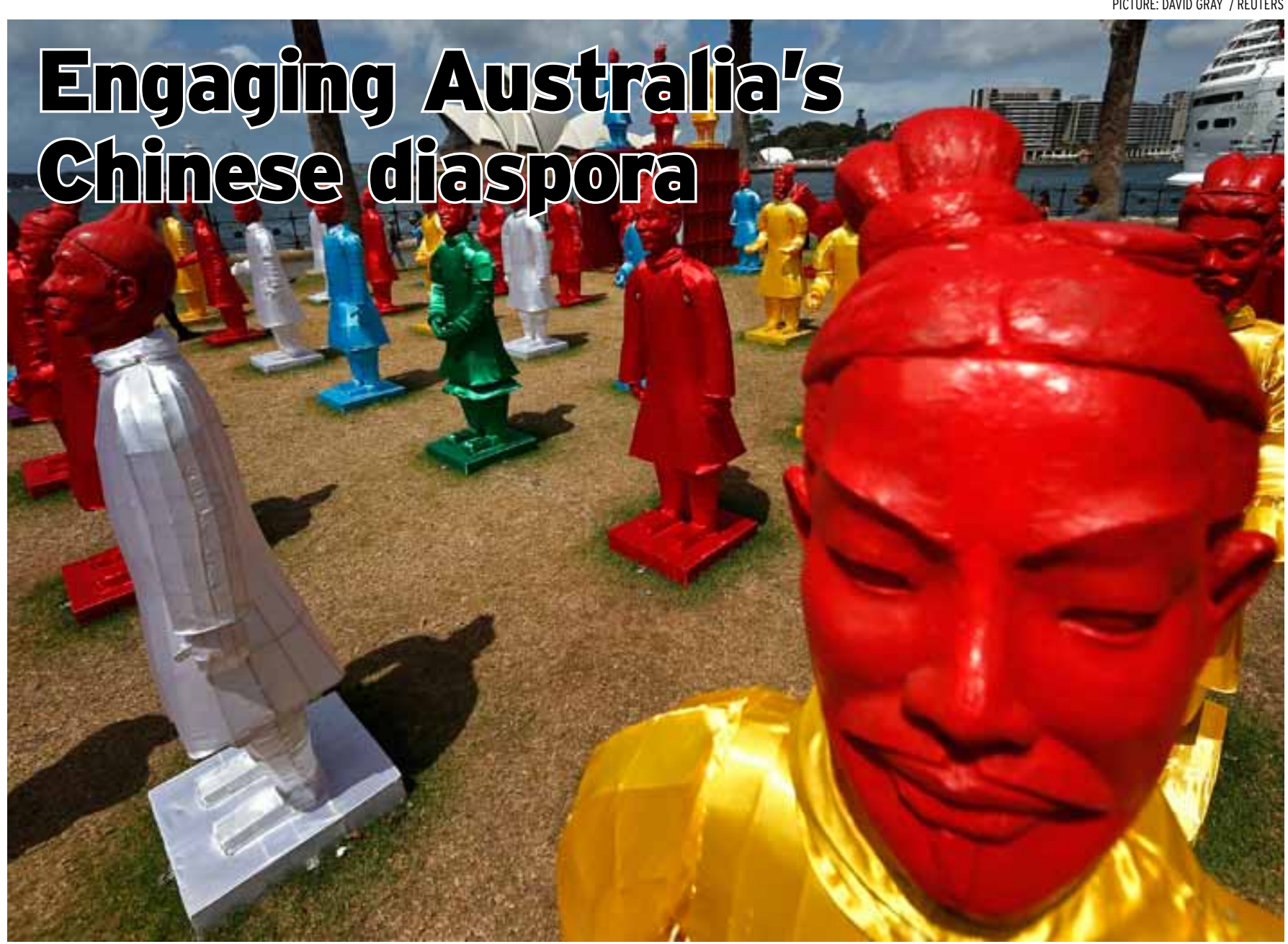

IEN ANG

INCE the opening of China's
economy in 1978, emigration from China has steadily gathered pace. The number of Chinese from the mainland living and working overseas rose from 4.1 million in 1990 to 9.3 million in 2013.

This recent wave of Chinese migration is very different from earlier Chinese migrations and has taken place against the backdrop of China's increasing economic prosperity and global clout. Those who have left China come from a range of backgrounds, including unskilled workers, students, highly skilled professionals and wealthy investors.

The rise in the number of highly skilled and wealthy Chinese migrating overseas has been particularly significant in countries that had a history of restrictions on Chinese and other Asian migrants. Chinese nationals now dominate many of the skilled migrant and investor immigration pathways put in place by countries such as the United States, Canada and Australia. Since the abolition of racially discriminatory immigration policies in the 1960s and 1970 s, these countries have opened themselves up to migration from Asia, resulting in a huge increase in Chinese migrants.

In Australia, census data show that the mainland-born Chinese population surged from 25,883 in 1981 to 526,000 in 2016. This represents a twentyfold
Ancient presence: an art installation, Lanterns of the Terracotta Warriors, in front of the Sydney Opera House in February 2015, during Sydney's Chinese Lunar New Year Festival.

increase in 35 years. The China-born are now the country's third largest migrant group-behind those of the United Kingdom and New Zealandand accounts for 2.2 per cent of the Australian population.

In Sydney, Australia's most populous city, the Chinese diaspora already represent the largest migrant group. In some suburbs-such as Hurstville, Rhodes and Burwood-at least a quarter of residents were born in mainland China.

In Haymarket, where Sydney's Chinatown is located, 19 per cent of 
residents were born in China, while people of Chinese ancestry-including those who are descendants of earlier Chinese migrants and those from Hong Kong, Taiwan or other diasporic locations-make up 32 per cent. This is a pattern reflected in Vancouver and the west coast of the United States.

These statistics paint a dramatic picture of the scale of Chinese diaspora presence in Australia, and parts of North America, whose impact is strongly evident in neighbourhoods, workplaces and schools.

China's growing global strength and associated assertiveness, coupled with its economic importance to Australia and many other countries, has spawned an intensifying debate about the future of Australia's relationship with China. And the Chinese diaspora has of course been drawn into these debates.

But what's absent from the debate is reflection on how the contributions of Australia's Chinese diaspora might be leveraged to enhance the relationship in ways that serve Australian interests.

Instead, the impact of Chinese presence in Australia tends to be understood within a narrow and nationalistic framework, in which the Chinese diaspora is increasingly being treated as a threatening and not-to-betrusted minority.

C HINESE investors are blamed for the exorbitant rise in housing prices in Sydney and there is confusion in the Australian public about the difference between domestic Australian Chinese investors and foreign Chinese investors. There's racially tinged anxiety about selective schools becoming dominated by Chinese and other Asian students.

In the past year, media reports about the alleged meddling of the Chinese Communist Party in
Australia's domestic affairs have

heightened public distrust of the Chinese diaspora. These reports have been fuelled by suspicion regarding local Chinese business donations to political parties and universities and the belief that Chinese international students are attempting to curb free speech in university lectures.

Sophisticated debate on these matters is essential if Australia is to maintain a healthy relationship with China. That's not helped by fixating on the threat posed by China and by extension, the Chinese diaspora. The Chinese-Australian population, like similar groups in Canada, the United States and elsewhere, is clearly not an homogenous group, bent exclusively on serving the interests of its country of origin or heritage.

Among other elements, the voices of ordinary Chinese Australians themselves need to be heard. It would also help if debate moved beyond crude notions of antagonistic national interests towards more constructive explorations of transnational collaboration for mutual benefit.

The mediating role of the Chinese diaspora in advancing business and cultural links between Australia and China is one dimension of this perspective. Chinese migrants-as owners of, or key decision-makers in, Australian companies-play a positive role in assisting trade and investment relations with China. Through their 'bicultural' social and cultural capital, including language skills, knowledge of how Chinese business operate and access to co-ethnic transnational networks, they facilitate the entry of Australian companies into the Chinese market.

Something similar is taking place in scientific research. Chinese researchers working at Australian research institutions have played a critical role in driving Australia's research collaboration with China.

Data show Australian researchers of Chinese origin are disproportionately engaged in such collaborations. Measured by co-authorship of refereed journal articles, they account for 66 per cent of publications involving coauthors based in Australia and China.

Australia uses diasporic Chinese researchers for research collaboration and knowledge exchange with China. It is through them that transnational knowledge networks and 'brain circulation' are nurtured. The same is the case for other Western countries which have a large Chinese diasporic research workforce, such as the United States.

$\mathbf{Y}$ ET there are few science diplomacy strategies in place to leverage this capacity in both countries' mutual interests. One survey showed that the overwhelming majority of diasporic Chinese researchers in Australia would be prepared to work on strengthening research collaborations with their home country if given the opportunity to do so.

Countries like Australia, which host large numbers of China-born citizens and whose security and prosperity are increasingly dependent on close relations with China, would do well to invest in new diaspora engagement strategies.

This would ensure that Australia's and others' relationships with China remain on an even footing in a world in which, in the not too distant future, China may be the leading global power. EAFQ

Ien Ang is Distinguished Professor of Cultural Studies at the Institute for Culture and Society at Western Sydney University. 


\section{Australian National University}

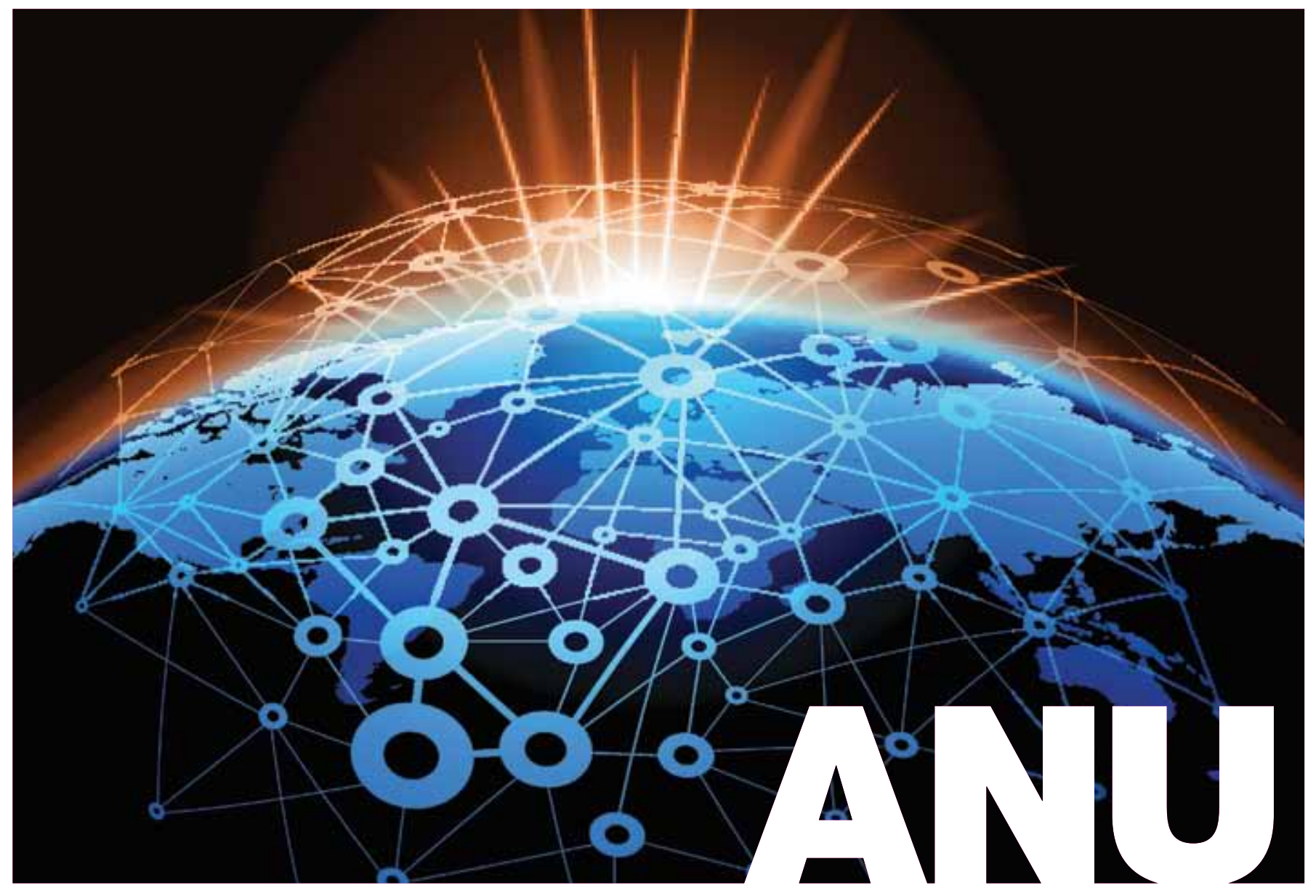

\section{EXPANDING \\ YOUR POLICY UNIVERSE}

The Crawford School of

Public Policy is Australia's leading voice for policy research and engagement.

Crawford School of Public Policy ANU College of Asia \& the Pacific
When you study a postgraduate degree at Crawford, you'll become part of a rich tradition that enables measurable impact through real-world engagement within Australia and beyond.

Crawford students participate in the region's most renowned and respected policy forums and our research centres have been informing and leading public policy debate since we were established.

At Crawford, you will become part of the policy universe - a network of public policy professionals committed to finding evidencebased solutions to issues like water, food, energy, economic development, the environment and governance.

Through deep engagement with policymakers you'll learn how to make change happen.

\section{Contact}
W crawford.anu.edu.au
E crawford@anu.edu.au
$f$ CrawfordSchool
@ANUCrawford

CRICOS Provider \#00120C 